\title{
Why non-native grasses pose a critical emerging threat to biodiversity conservation, habitat connectivity and agricultural production in multifunctional rural landscapes
}

\author{
Robert Godfree $\mathbb{C} \cdot$ Jennifer Firn $\cdot$ Stephanie Johnson • Nunzio Knerr • \\ Jacqui Stol · Veronica Doerr
}

Received: 8 April 2016/Accepted: 7 April 2017/Published online: 8 May 2017

(C) The Author(s) 2017. This article is an open access publication

\begin{abstract}
Context Landscape-scale conservation planning is key to the protection of biodiversity globally. Central to this approach is the development of multifunctional rural landscapes (MRLs) that maintain the viability of natural ecosystems and promote animal and plant dispersal alongside agricultural land uses.

Objectives We investigate evidence that non-native grasses (NNGs) in rangelands and other low-intensity agricultural systems pose a critical threat to landscape conservation initiatives in MRLs both in Australia and globally.
\end{abstract}

Electronic supplementary material The online version of this article (doi:10.1007/s10980-017-0516-9) contains supplementary material, which is available to authorized users.

R. Godfree $(\bowtie) \cdot$ N. Knerr

CSIRO National Research Collections Australia,

GPO Box 1600, Canberra, ACT 2601, Australia

e-mail: Robert.Godfree@csiro.au

\section{J. Firn}

School of Earth, Environmental and Biological Sciences, Queensland University of Technology (QUT), Brisbane, Australia

S. Johnson

La Trobe University, Bundoora, VIC 3083, Australia

J. Stol · V. Doerr

CSIRO Land and Water Flagship, GPO Box 1700,

Canberra, ACT 2601, Australia
Methods We first establish a simple socio-ecological model that classifies different rural landscape elements within typical MRLs based on their joint conservation and agro-economic value. We then quantify the impacts of eight Australian NNGs (Andropogon gayanus, Cenchrus ciliaris, Eragrostis curvula, Hyparrhenia hirta, Nassella neesiana, Nassella trichotoma, Phalaris aquatica and Urochloa mutica) on different landscape elements and then classify and describe the socio-ecological transformations that result at the MRL scale.

Results Our data indicate that two broad classes of NNGs exist. The first reduces both conservation and agro-economic value ('co-degrading' species) of invaded landscapes, while the second improves agroeconomic value at the expense of conservation value ('trade-off' species). Crucially, however, both classes cause hardening of the landscape matrix, agricultural intensification, reduced habitat connectivity, and the loss of multi-value land use types that are vital for landscape conservation.

Conclusions NNGs drive socio-ecological transformations that pose a growing threat to landscape-scale connectivity and conservation initiatives in Australia and globally. There is an urgent need for further research into the impacts of NNGs on habitat connectivity and biodiversity within multifunctional landscapes, and the socio-ecological goals that can be achieved when landscape transformation and degradation by these species is unavoidable. 
Keywords Fragmentation - Invasive grasses ·

Landscape conservation · Trade-off - Transformation . Connectivity

\section{Introduction}

The invasion of new habitats by non-native grasses (NNGs) can have profound implications for community dynamics, abiotic-biotic interactions, and the structure and provision of ecosystem processes and services (Strayer 2012). Some NNGs transform otherwise intact ecosystems by altering the cycling and composition of soil nutrients (Ehrenfeld 2003), soil water regimes (Holmes and Rice 1996), geomorphology and sedimentation (Eamer et al. 2013), and even fire regimes (Ehrenfeld 2010; Adie et al. 2011; MacDougall et al. 2013). Others quickly colonise and dominate disturbed systems (Firn et al. 2010; D'Antonio et al. 2011), and when coupled with anthropogenic drivers that increase their dispersal and fitness (e.g., MacDougall and Turkington 2005; MacDougall et al. 2014), have become major degraders of agricultural production systems. The role of such species as drivers of global environmental change and biodiversity decline is long recognised (Franklin et al. 2006; Friedel et al. 2011; Firn et al. 2013).

Yet, we believe the potentially serious consequences of these impacts for biodiversity conservation and habitat connectivity at the landscape scale remains poorly recognised. Impacts at this scale are critical, since biodiversity conservation has rapidly shifted in recent decades to embrace landscape-scale conservation planning which aims to support biodiversity alongside agricultural and other human land uses (Soulé et al. 2004; Worboys 2010; Doerr et al. 2011). These multifunctional (or multiple-use) rural landscapes (MRLs; Moilanen et al. 2005; Argent 2011; Polyakov et al. 2014) are ones in which native ecosystems are fragmented by other land uses or where agricultural use is extensive and mixed with biodiversity values throughout. But the fundamental tenet of landscape-scale conservation is that biodiversity can still persist in these landscapes if the relative composition of different land uses is carefully managed and if connectivity among elements in fragmented landscapes supports dispersal and other movement by a range of species (Crooks and Sanjayan 2006; Hilty et al. 2006; Smith et al. 2013).
Operationally, landscape-scale conservation initiatives involve three main activities (Whitten et al. 2011). First, additional protection is sought for areas of high conservation value. In rural landscapes these are usually areas that have not been subjected to agricultural intensification and the biotic homogenisation that accompanies the loss of specialist species in high input systems (Doxa et al. 2012; Bredemeier et al. 2015). Second, management of human-dominated areas is adjusted to create more of a balance between conservation and human needs. These multifunctional areas may be spatially planned to serve as buffers for high conservation value areas or may be part of a general mixed use 'matrix' (Mackey et al. 2010; Stutter et al. 2012; Smith et al. 2013). Finally, structural connectivity among areas of higher conservation value may be managed or restored to facilitate movement of species through the landscape (i.e., functional connectivity; Doerr et al. 2010). Contemporary conservation programs that include some or all of these activities include the Wildlands and Yellowstone to Yukon projects of North America (Van Der Windt and Swart 2008; Mattson et al. 2011), the Great Eastern Ranges and Gondwana Link initiatives in Australia (Whitten et al. 2011; Worboys and Pulsford 2011; Bradby 2013; Pulsford et al. 2013), and High Nature Value (HNV) farmland projects in Europe (Doxa et al. 2012; Aue et al. 2014).

There are three main reasons why we believe the power of NNGs to diminish or negate the positive work being done to generate and sustain MRLs is underappreciated. First, many NNGs challenge the pervasive environmental-agricultural weed dichotomy (viz., Stone et al. 2008), and drive changes in the biodiversity and economic value of recipient landscapes via multiple social and ecological (socioecological; Mansergh et al. 2008) pathways. Yet the integrated impacts of NNGs on the multifunctional nature of rural landscapes are rarely considered, with most studies focusing exclusively on either ecological or agro-economic impacts within a restricted set of landscape elements. Second, history seems to show that efforts to control NNGs have been generally ineffective at preventing either broad-scale spread or the accumulation of serious direct and indirect impacts in recipient socio-ecological systems, even when targeted early in the invasion process. Societal conflict over species value certainly impinges on the will and ability of land managers to control grasses used for 
pasture improvement (Grice et al. 2012; Driscoll et al. 2014), but the same cannot be said for a growing number of less-palatable species. Third, connectivity is a core component of most landscape-scale conservation initiatives, but it has proven easier to identify, manage, and restore connections associated with woody vegetation than those associated with grasses and other ground-based vegetation (Doerr et al. 2010). Yet it is the latter that dominate many MRLs and are often most prone to invasion by NNGs.

In this paper, we combine a review of relevant literature and investigation of Australian case studies to better understand the ways that NNGs drive biodiversity decline in multifunctional rural landscapes, and implications for landscape conservation. We do this by first identifying and classifying the ways that NNGs transform different rural landscape elements, and then link these changes to the overall conservation value and functional connectivity of MRLs in general. Specifically, our approach is to:

(1) Establish a simple, flexible model that defines MRL land use elements in terms of agroeconomic and conservation values;

(2) Use this model to articulate the goals of landscape-scale conservation initiatives conducted in MRLs globally;

(3) Use eight Australian case studies and a brief survey of the international literature to quantify the direct and indirect mechanisms by which NNGs transform MRLs; and

(4) Explore the losses in conservation value and functional connectivity likely to result from these changes in landscape composition and management.

We then discuss the importance and intractability of these processes in low intensity agricultural systems both in Australia and globally, and identify gaps in knowledge or capacity that influence our ability to preserve or re-connect these systems when NNGs are present.

\section{A multifunctional rural landscape model}

Many rural landscapes in Australia and other parts of the world are undergoing a multifunctional rural transition (Holmes 2006), in which biodiversity, ecological function and social amenity values are increasingly competing against traditional productivist agricultural land uses (McCarthy 2005). In these landscapes, knowledge of the joint agro-economic and conservation value of different landscape elements has become central to modern environmental decisionmaking (Moilanen et al. 2005; Whitten et al. 2011). It is therefore no longer possible to isolate the study of invasive or introduced species in these systems in a way that treats them as purely ecological or economic phenomena (Larson 2008), but as components of broader socio-ecological systems (Bardsley and Edwards-Jones 2007; Marshall et al. 2011) in which NNG-driven changes in anthropogenic and biophysical processes alter landscape function as a whole (Bart 2006; Bart and Simon 2013).

A model representing a socio-ecological value framework consistent with the structure of modern multifunctional rural landscapes (MRLs) is shown in Fig. 1a. For simplicity, and due to the pervasive lack of information on the impacts of most NNGs on social value and amenity, we specifically focus on core agroeconomic and conservation land use values, which remain critical in virtually all lightly populated rural landscapes in Australia and elsewhere. However, we discuss the impact of the spread of amenity landscapes, in which lifestyle attributes are highly valued (Klepeis et al. 2009), on NNG control below.

In this model, landscape elements can be classified into four general types: conservation, agricultural, degraded, and multi-value (Fig. 1a). Examples of conservation landscape elements, which are cornerstones of environmental planning (sensu Margules and Pressey 2000), include areas of on-farm native vegetation with no or only very low intensity livestock grazing (Fig. 1a), national parks, wildlife refuges, bogs, wetlands, and significant roadside vegetation. Areas withdrawn from agricultural production under the US Conservation Reserve Program (Morefield et al. 2016) or similar set-aside schemes (e.g., Van Buskirk and Willi 2004), and through grants, tenders, or other market-based instruments (Windle and Rolfe 2008; Cooke and Moon 2015) fall into this category.

Agricultural landscape elements with lower biodiversity value include irrigated and non-irrigated crops, improved high-input non-native pastures, managed intensive rotational grazing systems, exotic and native forest industry tree plantations, woody or grassy crops for biofuel production (e.g., willow, poplar, switchgrass), and orchards. These roughly correspond to 
a Multifunctional rural landscape
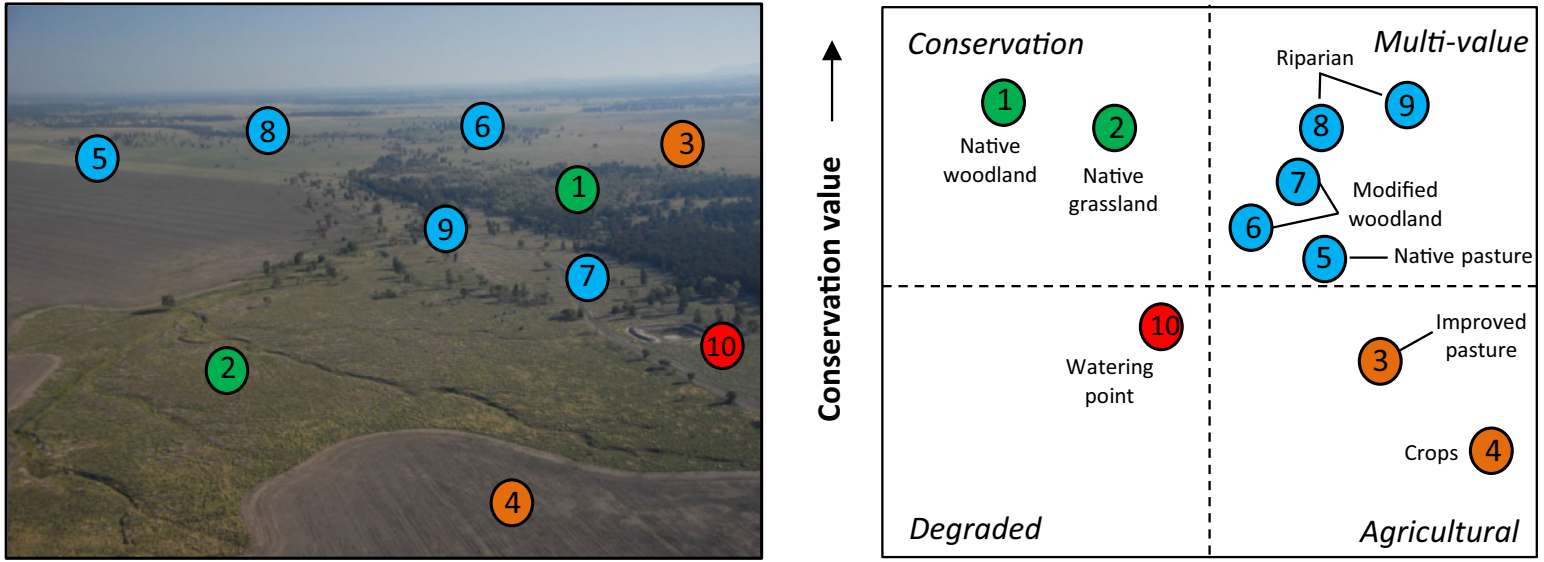

Agro-economic value
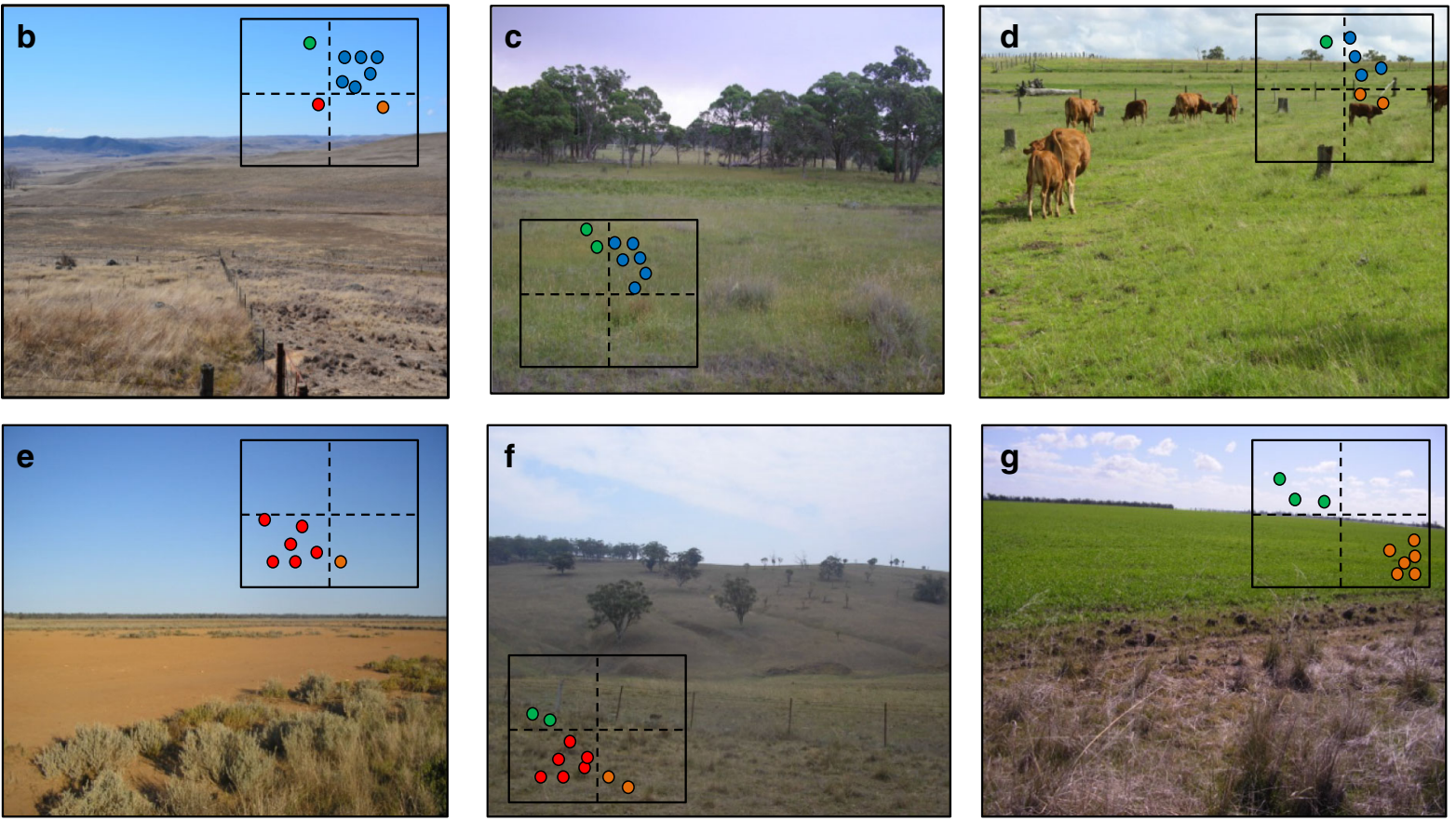

Fig. 1 A conceptual socio-ecological landscape model. a Multifunctional landscape in central New South Wales (NSW) containing elements that are of mainly single-value (green conservation; orange agricultural), little value (red degraded), or with both biodiversity and agricultural value (blue). Biodiverse mixed pastures (5), modified woodlands $(6,7)$ and riparian systems $(8,9)$ are the main multi-value areas. b-d Landscapes dominated by multi-value grazed native vegetation; b high altitude rangeland in southern NSW; c grassy woodland in central eastern NSW; d Subtropical grassland in south-eastern Queensland. e-g Degraded landscapes. e eroded semi-arid rangeland, western NSW; f degraded rangeland with some remnant woody native vegetation in central NSW; $\mathbf{g}$ extensive cropping in former native grassland (foreground); western NSW. In (g) the landscape is polarised into discrete areas of high conservation and high agronomic value. Photos Malcolm Carnegie (a), R. Godfree (b, c, e-g), J. Stol (d). (Color figure online) 
Holmes' (2006) productivist mode of rural land use. Globally, many productivist systems are expanding rapidly: for example, total global crop area increased by around ten million hectares per year between 2002 and 2011 (Grassini et al. 2013), while tree plantations expanded by $48 \%$ between 1990 and 2010 (Kröger 2014). Degraded elements include eroded, scalded, salinised or waterlogged soils, and overgrazed vegetation. It is estimated that land degradation hotspots cover around $29 \%$ of the global land surface area, with grasslands most severely affected (Le et al. 2014).

Of primary concern in this paper are managed, multi-value landscape elements, in which agricultural production and environmental conservation are both important goals. Although many extensive landscape elements potentially fall into this category (e.g., HNV farmland, riparian systems, silvicultural areas), our main focus here is on rangelands and pastures. These are arguably the most geographically extensive land use systems on earth (Asner et al. 2004), and perform vital socio-ecological roles throughout central and southwestern North America, southern and eastern South America, Africa, southern Europe, central Asia and Australia. Most consist of extensive, grassy or shrubby ecosystems, especially prairies, steppe, pampas, savannas, and open woodland.

In Australia, these systems are of exceptional importance. Grazed natural or modified grasslands and woodlands (Fig. 1b-d) cover 3.6 million $\mathrm{km}^{2}$ (ABARE-BRS 2010), generate in excess of AU $\$ 10$ billion annual in livestock production, and contain the majority of the continental native vegetation. Historically, many have suffered significant degradation (primarily as a result of overgrazing, often combined with drought; Fig. 1e-f), and so modern projects usually focus on converting single-use agricultural or degraded production areas into connected, multi-value or conservation-oriented landscape elements. This is achieved through improved fencing and grazing management (O'Reagain et al. 2014), protection of remnant woodland and watercourses, and in severely degraded areas (Fig. 1e-g), through construction of water management features, livestock exclusion, and revegetation (Ludwig and Tongway 1996). Large multi-value areas can play a vital role in preserving landscape biodiversity (McIntyre and Hobbs 1999, Smith et al. 2013), but even when spatially restricted they can buffer remnant native vegetation and provide supplementary habitat for native species, a process known as "matrix softening" (Haddad et al. 2014).

Following from this model, management practices that increase the conservation and agro-economic values of a given MRL simultaneously (Fig. 2a) represent particularly attractive 'win-win' scenarios [Fig. 2b; cf., the 'marginalised agricultural mode' of land use in Holmes (2006)]. For example, improved livestock management in degraded rangeland can reduce erosion, increase production, and enhance biodiversity (O'Reagain et al. 2014). Alternatively, conservation value may also be increased at little or no cost to agricultural profitability, for example by exchanging non-native for functionally similar native pasture species ('conservation gain'; Fig. 2b). However, trade-offs (win-lose scenarios) may also be necessary to protect high quality habitat from further degradation by limiting or removing agricultural use ('conservation trade-off'; Fig. 2b), perhaps coupled with the sacrifice of conservation value in other areas ('agricultural trade-off'; Fig. 2b; often termed "environmental offset arrangements"; Hayes and MorrisonSauders 2007). At the landscape level, some or all of these trajectories contribute to a transformation process (Fig. 2a) that generates landscapes compositionally capable of fulfilling multiple socio-ecological functions.

\section{NNGs in multifunctional rural landscapes}

To understand the way that NNGs transform MRLs we first need to identify the ways that they change the agro-economic and conservation value of landscape elements in which they occur. To achieve this we used a case study approach, focusing on eight representative NNG species in Australia (Table 1). Four are palatable pasture grasses (Andropogon gayanus, Cenchrus ciliaris, Phalaris aquatica and Urochloa mutica; authorities provided in Table 1), while the rest are undesirable, mainly low palatability species (Eragrostis curvula, Nassella neesiana, Nassella trichotoma and Hyparrhenia hirta). All have broad distributions in Australia (Fig. 3a-h), occur in multivalue grazed native and modified vegetation that represent a large proportion of the continental biota (Table 1; Fig. 4), and have potential ranges that span many of Australia's most important ongoing landscape-scale conservation and corridor initiatives 
a

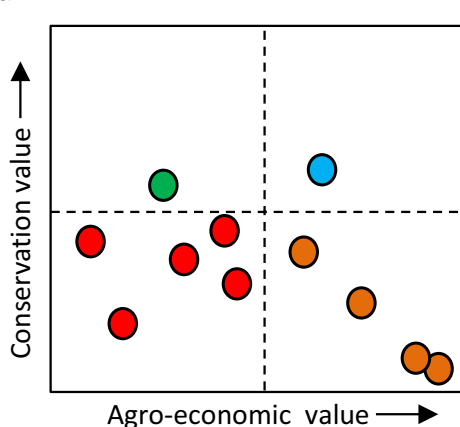

b

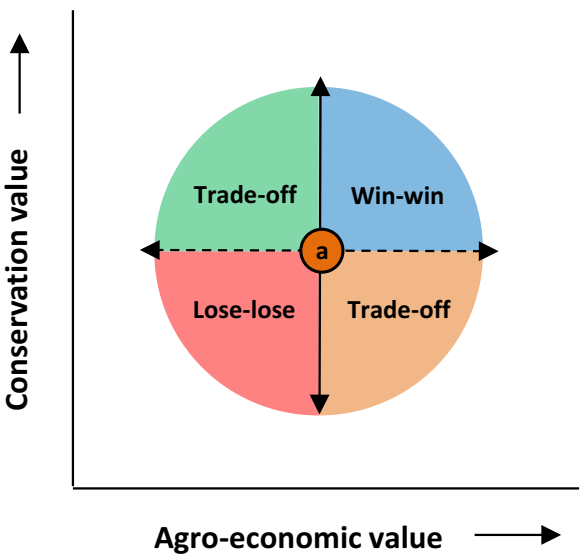

Transformation

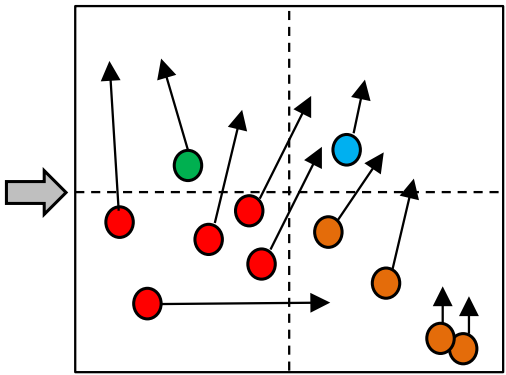

Final SES state

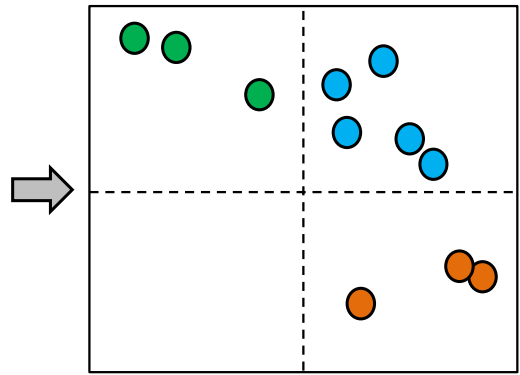

Trajectory

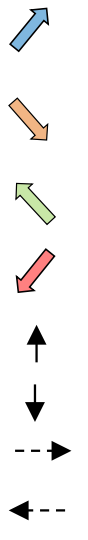

Win-win $(W-W)$

Agricultural

trade-off (AT)

Conservation trade-off (CT)

Lose-lose (L-L)

Drivers

Shelter belt plantings, erosion and salinity control, drought fodder reserves, rotational grazing

Fertilisation, introduced pastures, agricultural intensification, land clearing

Land acquisition for National Parks, conservation areas, etc., agricultural deintensification

Overstocking, soil compaction, salinity, weed invasion, feral animals

Conservation gain (CG) Revegetation, species reintroductions

Conservation loss (CL) Species decline in reserves, genetic homogenisation

Agricultural gain (AG)

Crop/livestock improvement

Agricultural loss (AL)

Crop disease, nutrient loss etc.

Fig. 2 Potential trajectories of socio-ecological change in multifunctional landscapes. a Transformation of a landscape from one dominated by single-use and degraded socioecological values to a higher value multi-value state with improved biodiversity conservation and connectivity. b Potential socio-ecological trajectories of a given landscape element (labelled a) fall into four main scenarios: 'win-win', where

(Fig. 4). Many are also invasive outside of Australia (e.g., Arriaga et al. 2004).

Table 2 summarises information on fourteen agroeconomic (1.1-1.7) and conservation (2.1-2.7) drivers through which NNGs transform different landscape elements, and the trajectories that lead to broader landscape and socio-ecological change. These drivers, which were selected on the basis of a review of the relevant literature for each species (see Online Appendices 1-8), act either directly (1.1 and 2.1) or indirectly $(1.2-1.7 ; 2.2-2.7)$ on recipient systems. Because different sources varied greatly in methodology, we simply scored the impact of each driver on conservation and agricultural value both improve; 'lose-lose', where both decline; 'conservation trade-off', where conservation value increases at the expense of agricultural value, and 'agricultural trade-off', where the reverse occurs. Four other restricted scenarios in which change occurs in only one value are also possible, involving agricultural gain or loss (dashed arrows) or conservation gain or loss (solid arrows)

agro-economic or conservation value (see Fig. 2) as negative $(-)$, positive $(+)$ or neutral $(0)$, or a combination of both $( \pm$ or $->+$ if a clear difference in importance). For example, $N$. trichotoma reduces agro-economic value by reducing pasture production ( - score), C. ciliaris increases pasture value (+score), and $H$. hirta reduces pasture production and hence agro-economic value except under restricted circumstances $(->+$ scoring). Drivers of special importance were also noted for each species; for example fire regime change is a key driver of conservation value loss associated with A. gayanus (-*; Table 2). Consensus socioecological trajectories were then 


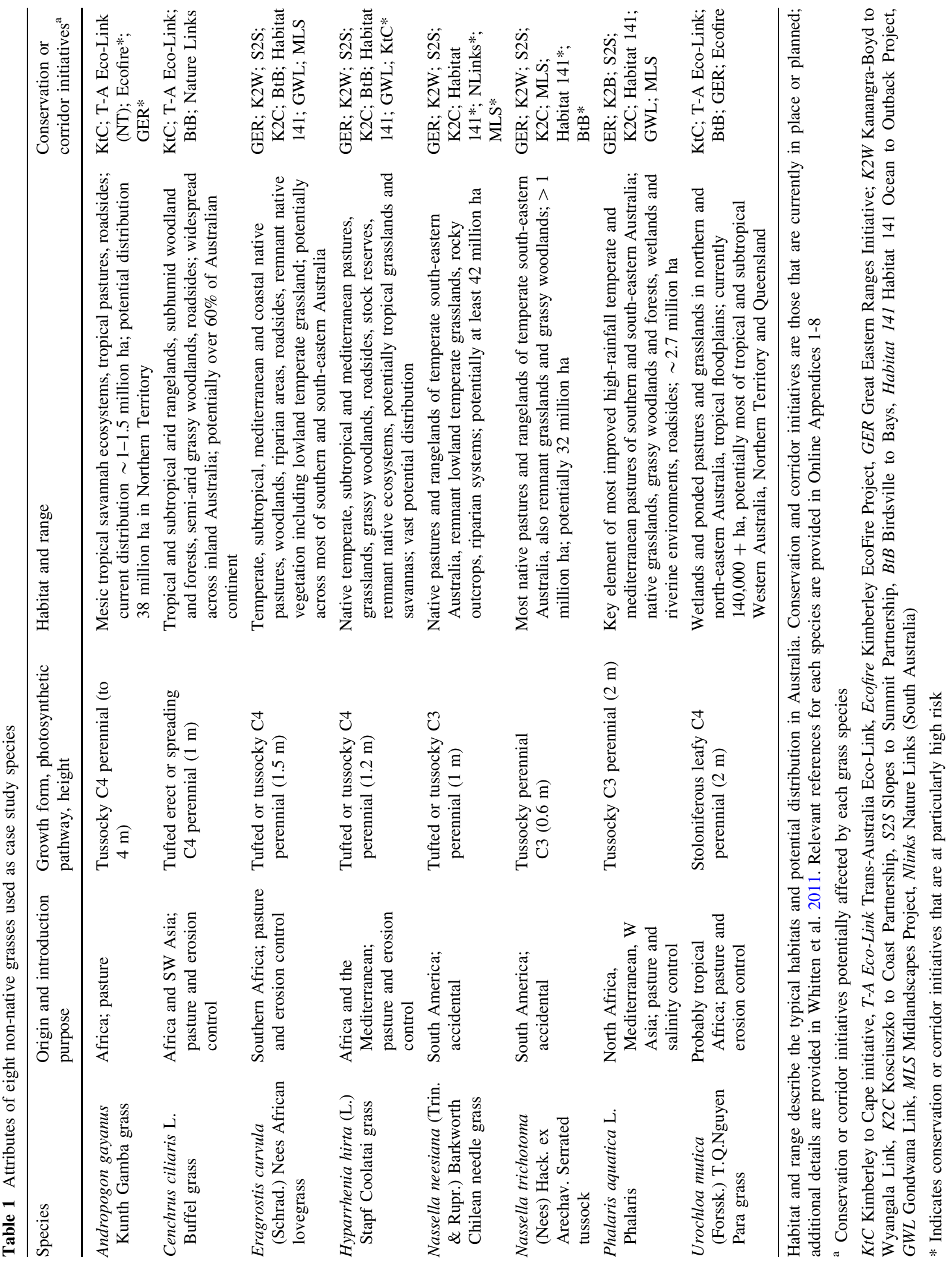


Fig. 3 Distribution of eight case study non-native grasses in Australia. Spatial data obtained from the Australia Virtual Herbarium (Council of Heads of Australasian Herbaria; http://avh.chah.org.au/) a

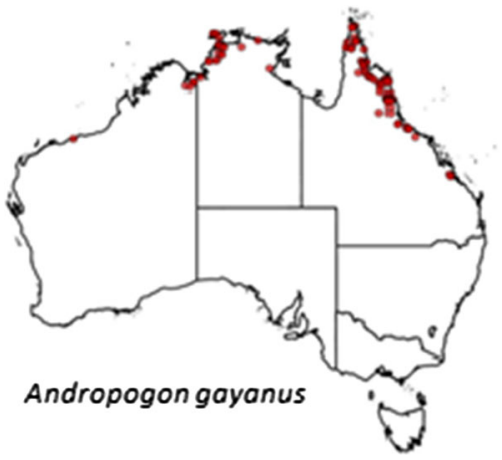

C
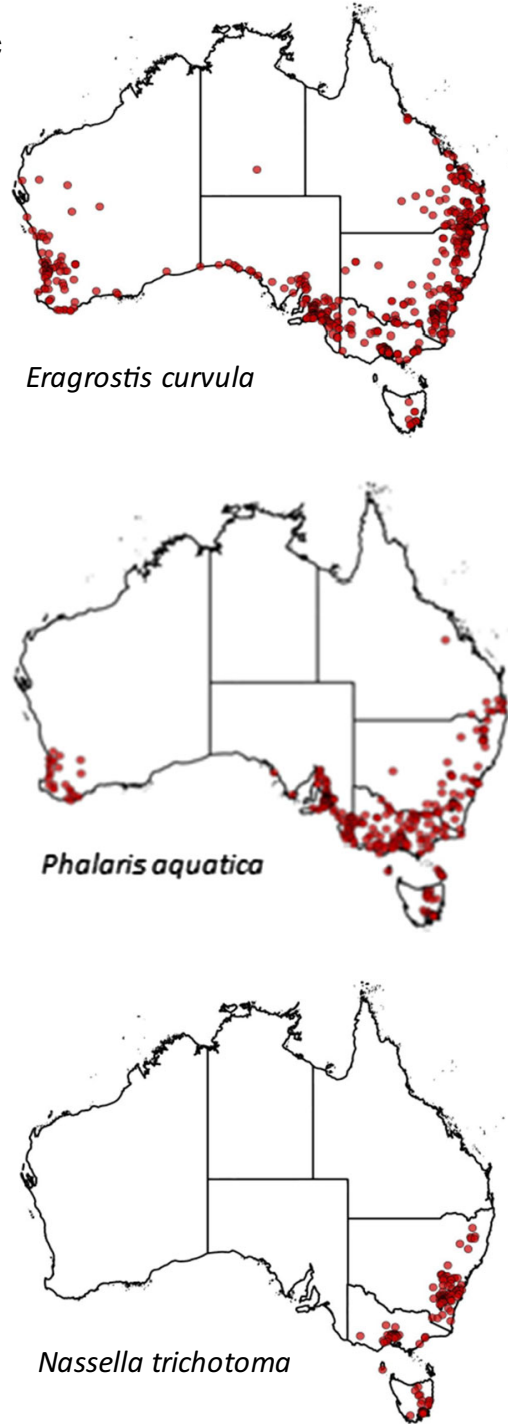

b
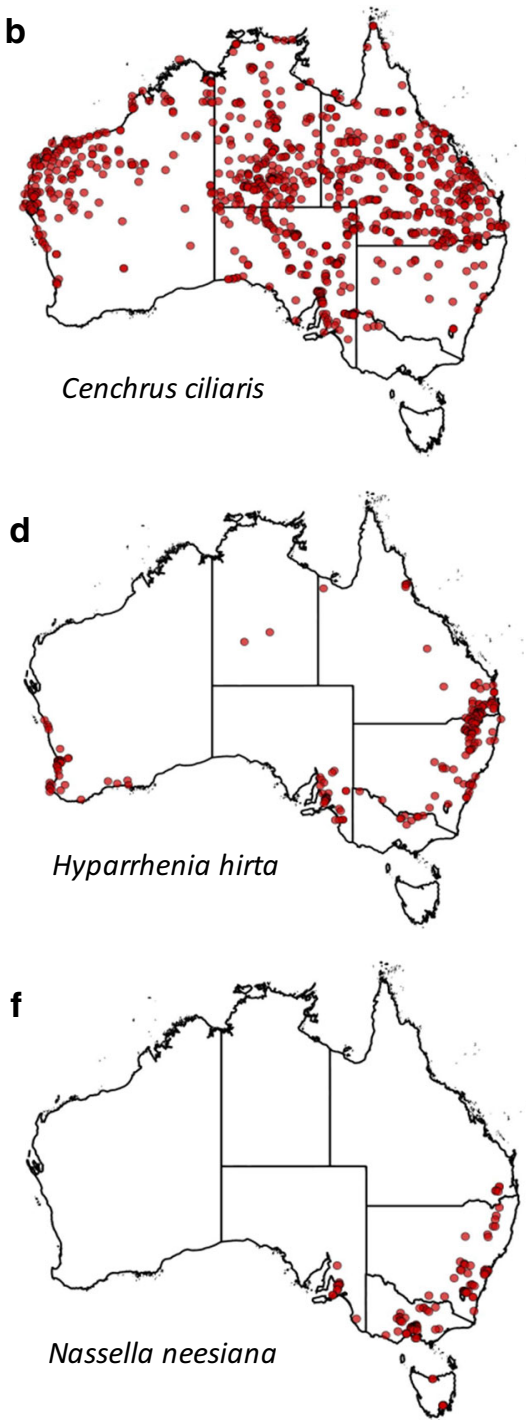

h

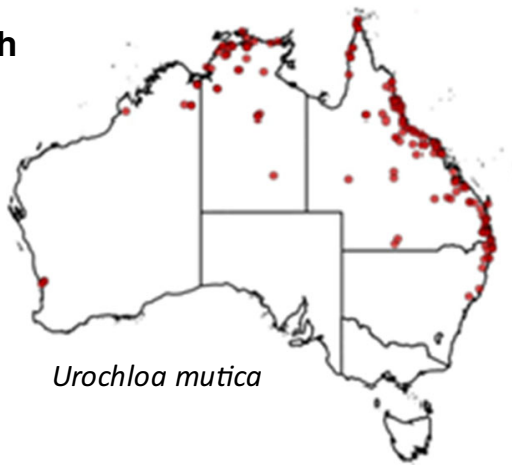

constructed for each landscape element class (Fig. 1). In the following discussion we refer to only a selection of representative data to illustrate these processes; readers are referred to Online Appendices 1-8 which contain detailed, speciesspecific notes and references. 


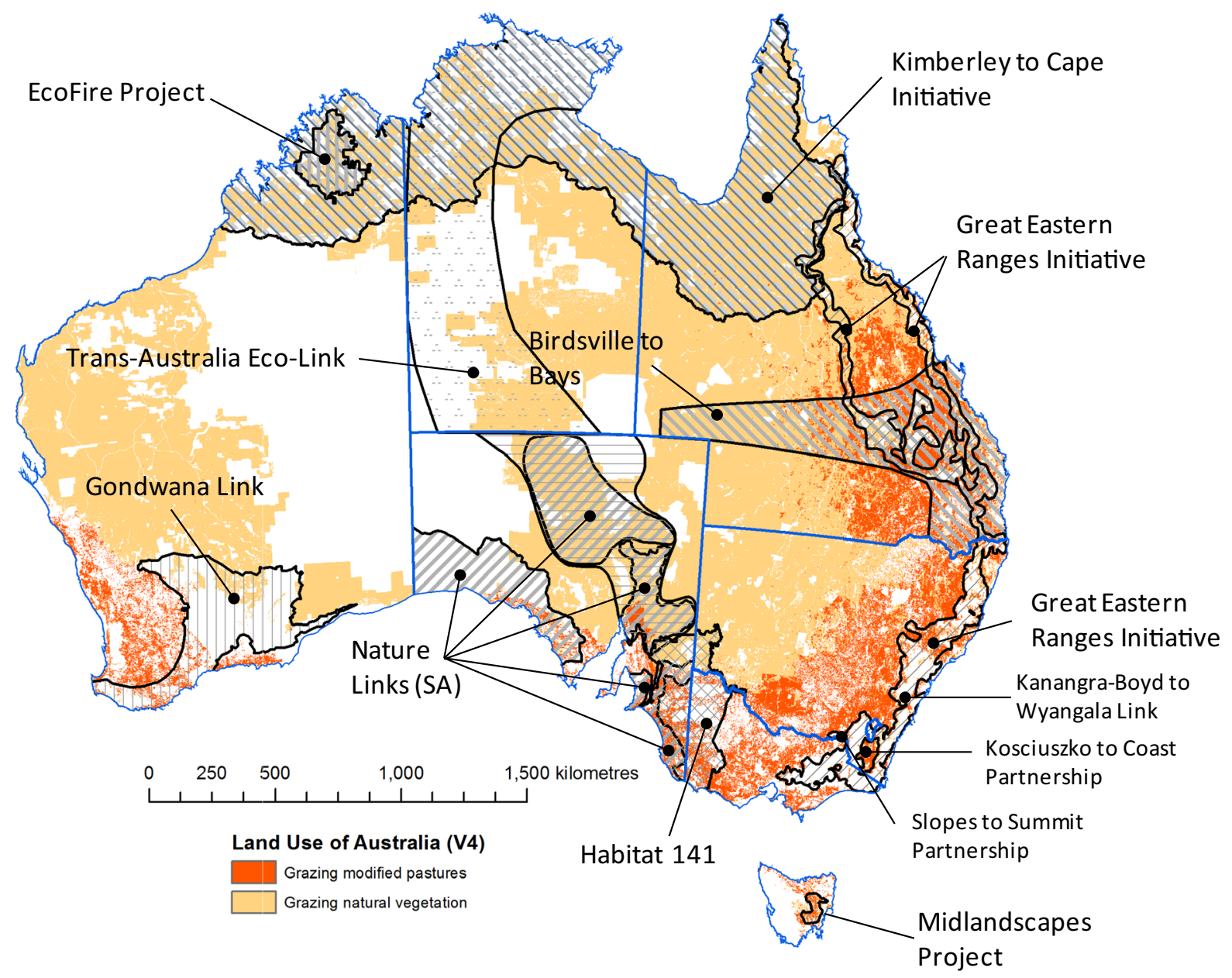

Fig. 4 Spatial extent of current and proposed landscape connectivity and corridor initiatives in Australia, along with two multi-value grazing land use types that retain significant native biodiversity. Connectivity and corridor initiatives are

Our data indicate that the eight NNGs transform MRLs in two main ways. First, low palatability species (N. trichotoma, N. neesiana, E. curvula and $H$. hirta) typically drive landscape elements along lose-lose, conservation loss or agricultural loss trajectories (L-L, CL and AL; Fig. 2b), leaving the MRL in an economically and ecologically degraded state. These we term Type I or "co-degrading" transformations (Fig. 5a). In contrast, $P$. aquatica, $C$. ciliaris, $U$. mutica and $A$. gayanus generally increase agricultural production at the expense of conservation value (AT trajectories; Fig. 2b) in all but the most degraded land use types, which we call Type II or "trade-off" transformations (Fig. 5a). Landscapes altered by codegrading transformations are likely to contain an from Whitten et al. (2011) while land use data are from land use of Australia 2005-06, Version 4 (ABARE-BRS 2010). ${ }^{\circ}$ Department of the Environment 2015

extensive matrix of impoverished rangeland and pasture surrounding smaller areas of intensive agriculture or remnant vegetation (Fig. 5b, c), while tradeoff transformations result in more agriculturally productive landscapes of reduced conservation value (Fig. 5d, e). Both transformations represent a significant shift away from the target multifunctional state (Fig. 5a) and reverse gains made in landscape-scale conservation initiatives.

From an agro-economic perspective, co-degrading species reduce profitability by forming unproductive, often monocultural pastures (Fig. 6a; Campbell and Vere 1995; Lodge et al. 2005; Firn 2009). Eragrostis curvula, $H$. hirta and $N$. neesiana are occasionally viewed positively as pasture species (McLaren et al. 


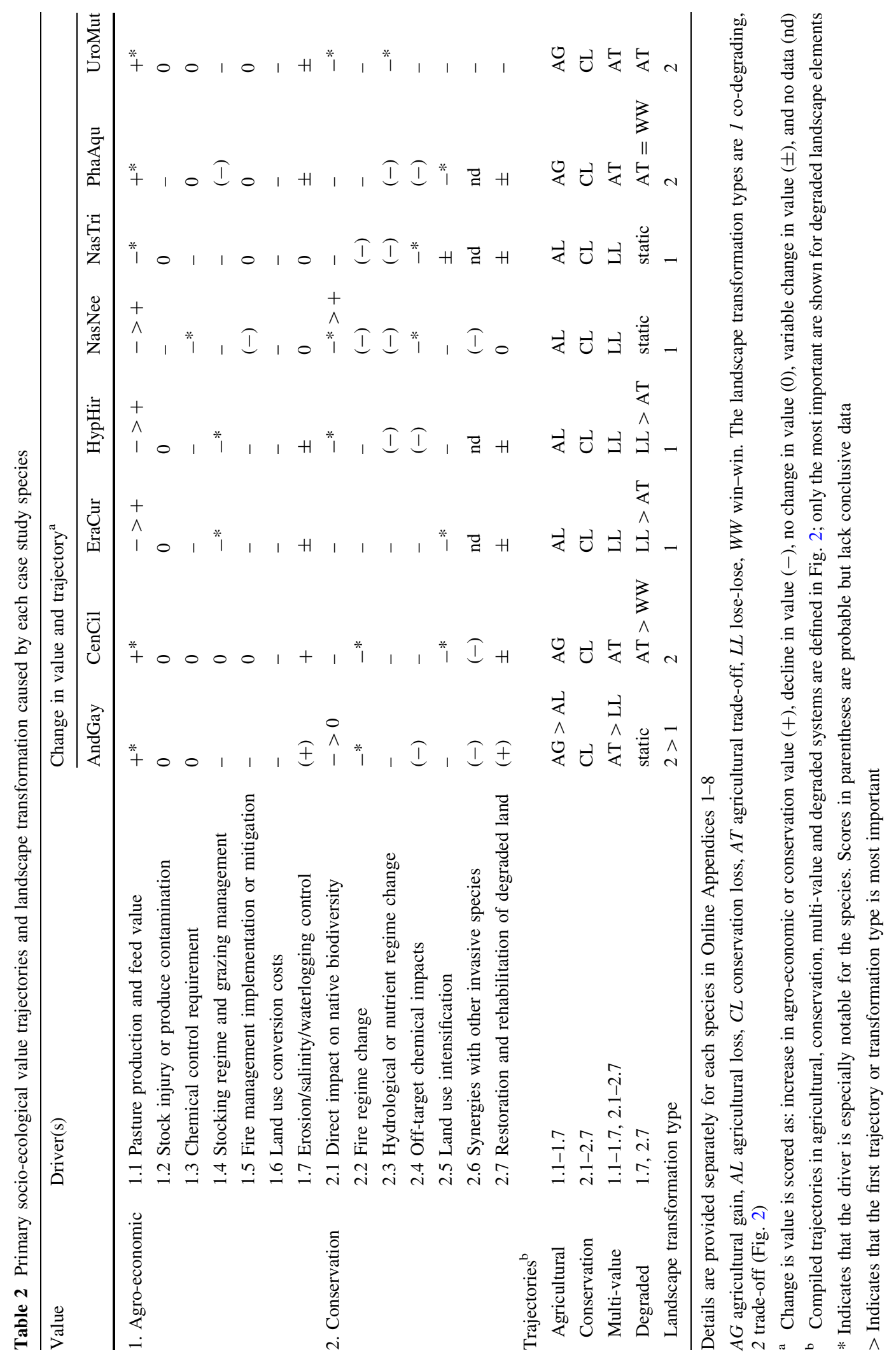


a Landscape transformation categories
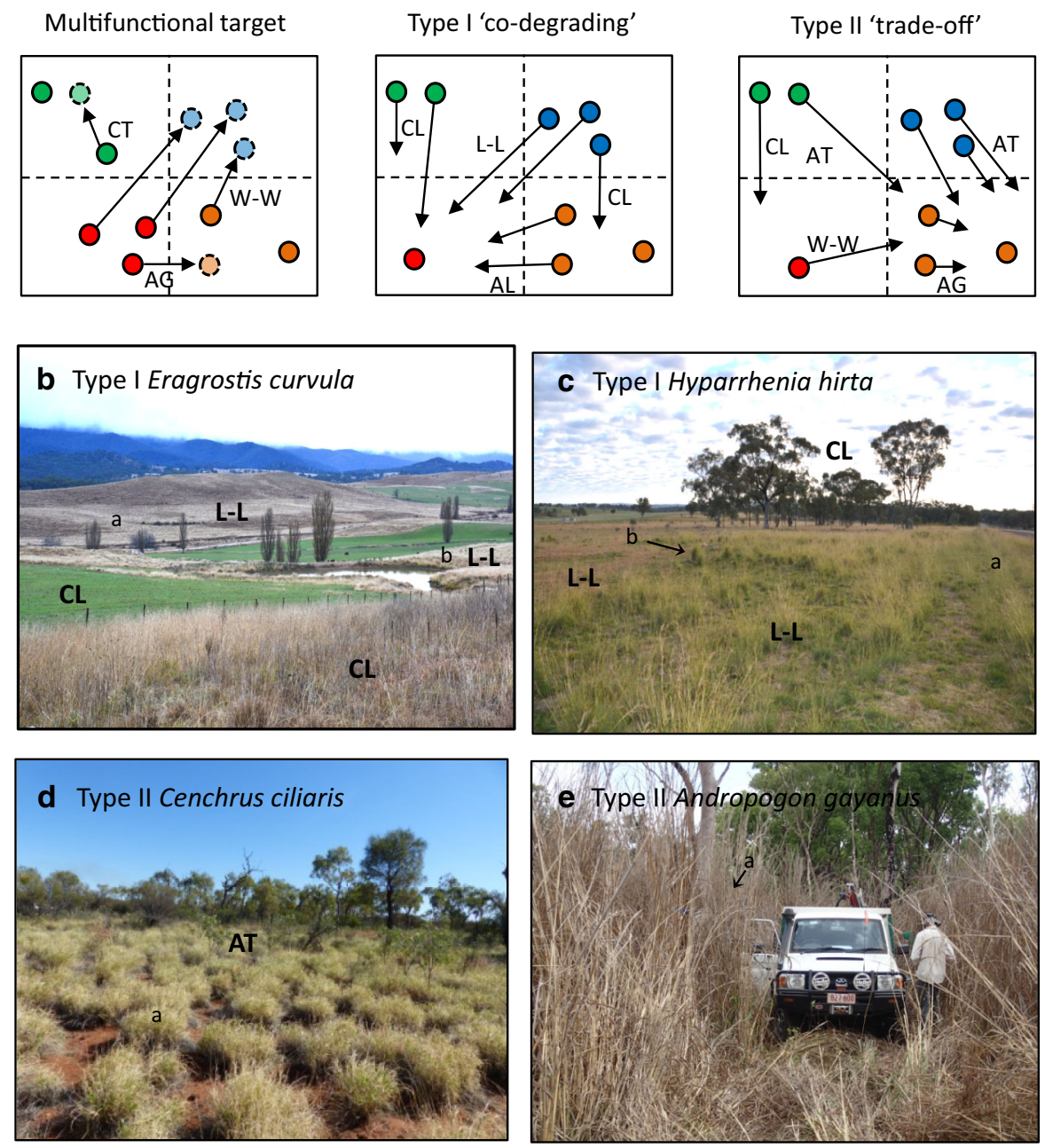

Fig. 5 Transformation of Australian rural landscapes by nonnative grasses. a Co-degrading and trade-off landscape transformations compared with the multi-functional target. b Invasion of the temperate pasture by Eragrostis curvula dominated by conservation loss and lose-lose trajectories. Eragrostis curvula is the light coloured grass on the lower slopes in the background ( $a$ ) and near the stock watering point $(b)$. c Active invasion of rangeland and remnant woodland in central NSW by Hyparrhenia hirta. The invasion front rapidly moves away from

the road verge $(a)$, with individual tussocks $(b)$ establishing in the semi-natural grassland to the left. d Cenchrus ciliaris in the arid zone of central Australia. Tussocks of $C$. ciliaris $(a)$ can form dense monocultures. e Invasion of grazed savannah in northern Australia by Andropogon gayanus. Dense stands can develop under the native woody overstory, sometimes exceeding $3 \mathrm{~m}$ in height (a). Photos R. Godfree (b, c); Kerrie Bennison (d); Damien McMaster (e)

2002; McArdle et al. 2004), but the consensus is that all three species should be eradicated or controlled if possible. Indeed, maximising their palatability using fire (Fig. 6b), controlled stocking rates, mowing and/ or fertiliser application (Fig. 6c; Snell et al. 2007; Osmond et al. 2008; Firn 2009; Grech et al. 2014) all incur large infrastructure and equipment costs which are often of marginal economic viability. They also

often require expensive broadacre chemical control that generates phytotoxic effects on favourable species (Osmond et al. 2008) and encourages other broadleaf weeds (Fig. 6d). Pasture renovation and conversion to rotational cropping are land use conversions (Table 2; Online Appendices 3-6) that are costly to implement and restricted to more productive areas. Nassella neesiana seed also directly injures livestock and 

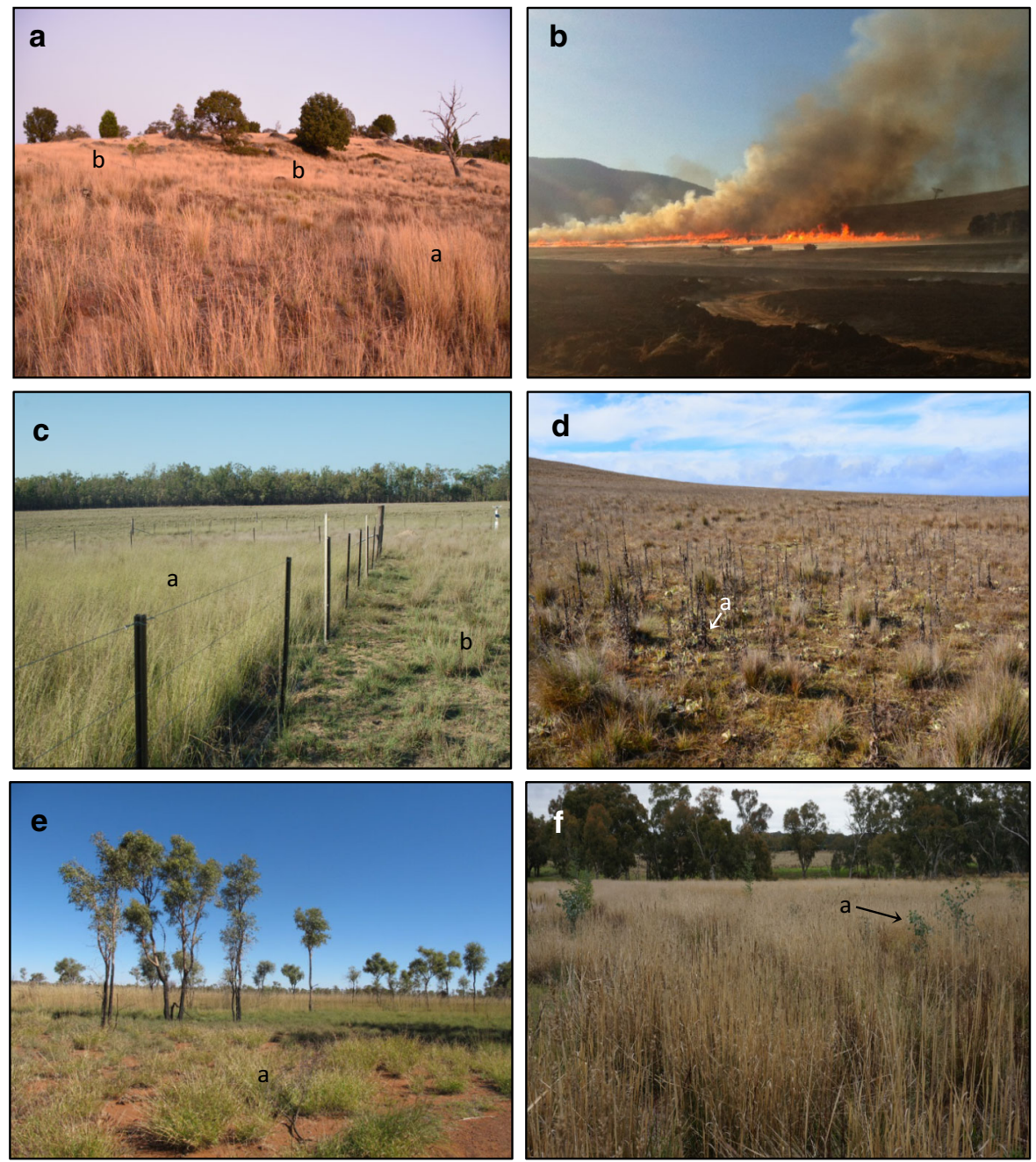

Fig. 6 Impacts of non-native grasses on landscape connectivity and conservation value. a Hyparrhenia hirta invading derived native grassland, Kanangra-Boyd to Wyangala Link (see Fig. 4). Dense clumps are shown in the foreground $(a)$ and background $(b)$. b Intense fires are characteristic of Eragrostis curvula-dominated grasslands, Kosciuszko to Coast Initiative. The image is of a heavily infested property being burnt to improve grazing value. Flame heights exceeded $4 \mathrm{~m}$ in areas of high standing E. curvula biomass. c Fertilisation and managed grazing intended to increase palatability of E. curvula. Ungrazed (a) and grazed (b) stands are indicated. d Phytotoxic effects of

downgrades wool, skins, hides and carcasses (Gardener et al. 2003). While H. hirta, E. curvula and other similar species have been used to rehabilitate degraded land, they are normally detrimental in these settings because they exclude the possibility of establishing more favourable species, leaving them in a static, degraded state (Table 2). herbicide use on non-target species in temperate grassland infested by E. curvula. The area indicated (a) has suffered from post-spray invasion by broadleaf weeds, especially Verbascum thapsus, following the chemical treatment of invading $E$. curvula. e Conversion of subtropical woodland to Cenchrus ciliaris pasture (a). f Infestation of a revegetation site in the slopes to summit partnership area by Phalaris aquatica. Dense stands greatly reduce the vigour of planted trees and shrubs $(a)$. Photos R. Godfree (a, d), J. Firn (c, e), J. Stol (f), Roger Roach (b)

In comparison, the trade-off species A. gayanus, $C$. ciliaris, $P$. aquatica and $U$. mutica have higher production value and fill significant temporal or spatial productivity gaps present in native pastures (Table 2; Tothill et al. 2008; Reed 2014). Costs associated with the establishment of these pasture species (Table 2), such as removal of pre-existing 
native vegetation (Fig. 6e; Tothill et al. 2008), construction of artificial pondages (U. mutica; Wildin 1985), and cultivation and/or fertilization (Hill et al. 2005) are small relative to productivity gains, and so their inclusion in grazing regimes is economically attractive. They also sometimes drive agricultural gain trajectories in degraded systems and only rarely drive win-win trajectories (Fig. 5a). In some cases, notably $P$. aquatica, they may also directly hinder restoration goals (Fig. 6f). Some overlap occurs between codegrading and trade-off species in economic value: for example, fast-growing tropical pasture grasses like $A$. gayanus can have greatly reduced economic value if not intensively managed for palatability, while the $E$. curvula cultivar Consol is moderately palatable and can add flexibility to some grazing enterprises (Johnston et al. 2005).

\section{Impacts on landscape conservation}

Our data indicate that all case study species alter landscape biodiversity on a scale that rivals that of cropping or other broadacre agricultural activities. The most obvious process is for infestations to form virtual monocultures in which other ground layer species (Ferdinands et al. 2005) are excluded from the recipient assemblage. Most NNGs grow rapidly and produce large amounts of standing biomass, which generates intense competition for soil nutrients, water and light with smaller understory or riparian plants (e.g., McArdle et al. 2004; Perna et al. 2012). This can occur on very extensive spatial scales (Table 1; Figs. 5b, d, e; 6a, c, f), leaving whole landscapes floristically impoverished, especially when other forms of disturbance, such as grazing or drought, affect the integrity of the existing native vegetation. All case study NNGs have a demonstrated capacity to directly exclude other vegetation, sometimes in the absence of significant anthropogenic disturbance; $H$. hirta, U. mutica and A. gayanus are outstanding examples (Table 2).

In most rural landscapes, however, indirect processes are probably more important drivers of native vegetation decline. Fire regime change is arguably the best example, with the dramatic ecosystem-transforming effects of the grass/fire cycle associated with $A$. gayanus threatening the long-term viability of much of the tropical savanna belt of northern Australia
(Rossiter et al. 2003; Brooks et al. 2010; Setterfield et al. 2010). There has been recent scientific debate over whether $C$. ciliaris causes the same phenomenon in semi-arid and arid ecosystems (Miller et al. 2010; Fensham et al. 2013), but the capacity for this species to modify fire regimes is also enormous (Grice 2006). Unusually intense fires have also been observed in stands of $U$. mutica, E. curvula, H. hirta and $P$. aquatica, and it is likely that the ecosystem-transforming effects of these species will increasingly be seen as a major problem for landscape conservation. Interestingly, awareness campaigns that highlight the danger of E. curvula fires to humans, infrastructure and livestock are currently underway in the Monaro Tablelands region of NSW.

Hydrological and edaphic change can also be a key transformative process when NNGs have seasonal resource requirements or morphological adaptations for soil water or nutrient extraction that differ from sympatric native species. This is certainly true of $A$. gayanus, which has an extended growing season compared with native grasses (Rossiter-Rachor et al. 2009) and $P$. aquatica, which increases pasture water use, reduces deep drainage (Johnston et al. 2003), but increases soil water deficits in dry times. The photosynthetic pathways of E. curvula, N. neesiana and $N$. trichotoma (Table 1) often differ significantly from the dominant grasses that they displace (e.g., Hattersley 1983), and so these species are also likely to alter soil water regimes in infested areas. Both $C$. ciliaris and $U$. mutica are major riparian weeds (Bunn et al. 1998; Marshall et al. 2012), with U. mutica drastically altering river sediment accumulation, streambed morphology and water discharge in infested catchments (Bunn et al. 1998). These changes have very significant indirect effects on associated riparian vegetation.

Agricultural intensification, which usually involves nutrient addition, pasture improvement, cropping, and increased grazing pressure, has a long track record of rapidly and dramatically altering rangeland and grassland composition both across Australia (Moore 1970; Dorrough et al. 2011) and globally (Tilman 1999; Sullivan et al. 2010), leaving impoverished or homogenised ecological systems. It is therefore crucial to understand that practices designed to establish, utilise or control NNGs often mimic, or even augment the broader process of agricultural intensification, and are probably the most important ways through which NNGs transform MRLs. This is most obvious with 
palatable pasture species: for example, the establishment of $C$. ciliaris in subtropical areas requires the preparation of target areas by clearing, tilling and/or fertilization, often followed by a significant increase in livestock density (Fig. 6e ; Tothill et al. 2008). Such practices can have a devastating impact on native vegetation and associated fauna, and currently represent a key threat to the retention of brigalow (Acacia harpophylla) and other woodland systems in northern Australia. In southern Australia the establishment of P. aquatica and other cool season perennial grasses (Reed 2014) has played a key role in reducing lowland temperate grassland to $<1 \%$ of its original extent (Groves and Whalley 2002).

Less recognized, however, is that unpalatable NNGs also drive similar or greater intensification of land use. For example, integrated control is often used to manage infestations of co-degrading NNGs, including $N$. neesiana (Snell et al. 2007), N. trichotoma (Osmond et al. 2008) and more recently E. curvula and H. hirta (Fig. 5b). This is usually based on broadacre herbicide application followed by cultivation and establishment of non-native pastures or annual crops, effectively removing large tracts of native vegetation. In rough, sloping or infertile areas normally considered unsuitable for cropping, such practices can also drive further ecosystem degradation via erosion, soil compaction, and loss of organic matter. The fact that this process has received little attention is surprising given that the conversion of grazing lands to more intensive pasture or cropping regimes on similar scales in response to other drivers (e.g., Zhang et al. 2006) is a serious contemporary threat to biodiversity conservation in Australian rangelands and native pastures. The use of fire as a management tool to maximise the palatability of undesirable species (e.g., H. hirta and E. curvula) also clearly has the potential to accelerate broad scale biodiversity loss in Australian rangelands and pastures, especially where the removal of NNG infestations is economically or biologically impossible (e.g., Lodge et al. 1994), and where native species have low tolerance to changing fire regimes.

Finally, a range of feedback mechanisms can drive further invasion and reinforcement of ecosystem change, a process known as invasional meltdown (Simberloff and Von Holle 1999). Few studies have investigated this process in MRLs, but one example is the provision of habitat to major pest fish species by $U$. mutica (cites in Perna et al. 2012). The impact of NNGs on fire, nutrient, water and light regimes may also precipitate self-facilitation or invasion by new species, as shown with A. gayanus and C. ciliaris (Rossiter et al. 2003; Jordan et al. 2008; Schlesinger et al. 2013). Another possible example is the planting of legumes with high phosphorous requirements to increase production of $P$. aquatica and other pasture species, leading to cascading changes in soil fertility that disadvantage native plants (Dorrough et al. 2011). Other complex interactions between factors such as competition, drought and grazing pressure can benefit unpalatable species like $N$. trichotoma (Badgery et al. 2008) and synanthropic pasture species like $C$. ciliaris (Marshall et al. 2012) at the expense of native species.

\section{Loss of landscape connectivity}

Given the capacity of NNGs to transform the structure and function of landscape elements critical to biodiversity conservation, it is surprising that the interaction between NNGs and landscape connectivity have rarely been explored. Nonetheless, there are at least three ways that NNGs are likely to erode functional connectivity for a substantial proportion of native species existing in MRLs.

First, in many MRLs the grassy understory is relatively continuous, even when associated woody vegetation has been fragmented (Mott and Groves 1994). Thus, invasion by NNGs may introduce an additional source of fragmentation, this time of the ground layer. As shown previously (Tables 1, 2), many NNGs have the capacity to form extensive monocultures which may superficially resemble native grasslands but more often vary both structurally and floristically (Daehler 2003; Brooks et al. 2010). Such habitat is likely to represent a significant barrier to movement and a reduced resource base for exploitation by native flora and fauna (e.g., Wolkovich et al. 2009). Concern has been raised that this process is occurring in the Monaro Tablelands of south-eastern NSW, where dense infestations of Eragrostis curvula (Fig. 5b) have developed along a $>50 \mathrm{~km}$ long corridor between Cooma (S 36.24 ${ }^{\circ}$, E $149.12^{\circ}$ ) and Canberra (S $35.28^{\circ}$, E $149.13^{\circ}$ ). The expansion of impoverished E. curvula grasslands is antithetical to the goals of the landscape-scale Kosciuszko to Coast (K2C) Partnership (Fig. 4), which is to protect and 
reconnect forest, woodland and grassland ecosystems in this region (Godfree and Stol 2015) while maintaining rangeland grazing.

Second, NNGs in the matrix create harder boundaries between the matrix and core reserves, thus increasing edge effects and reducing effective conservation patch size. This increases the distances between those patches, which in turn reduces functional connectivity (Soons et al. 2005). Third, fragmentation is likely to be greatly exacerbated by the agricultural intensification that accompanies the conversion of pasture land to more productive use (Type II species), or efforts to control low palatability (Type I) species (see above; Figs. 5, 6). A detailed review of the plants most affected by habitat fragmentation is beyond the scope of this paper (see Henle et al. 2004), but in general they include species that require frequent regeneration from seed, lack clonal or vegetative reproduction, have low natural abundance, depend on mutualistic relationships with a small number of pollinators or seed dispersers for reproduction, lack sexual self-compatibility, and occur in restricted or specialised habitats (Davies et al. 2000; Hobbs and Yates 2003; Marvier et al. 2004; Hoffmeister et al. 2005).

Subordinate ground-based plants, especially those with naturally short dispersal distances that require fairly continuous distributions to retain functional connectivity across the landscape, are likely to be especially at risk (Murphy and Lovett-Doust 2004). In Australia, these include perennial and annual forbs that occur in the interstitial space between grass tussocks and which comprise much of the floristic diversity of grassland communities (Trémont and McIntyre 1994; Williams et al. 2006). A similar situation exists in European semi-natural grasslands, where forbs generally suffer from greater dispersal limitation than sympatric grass species (Diacon-Bolli et al. 2013), ultimately suffering genetic erosion and increased extinction risk following habitat fragmentation (Broeck et al. 2015).

The extent to which NNGs directly disrupt or provide connectivity for ground-dwelling fauna has rarely been studied, and may often be highly speciesspecific. Nonetheless, reptiles, amphibians, and invertebrates can depend strongly on native grassy connections, even more than on woody connections (Brown 2000; Mac Nally and Brown 2001; de Castro and Fernandez 2004), and there is abundant evidence that the fragmentation of grassy ecosystems can affect plant-pollinator, predator-prey, host-pathogen and other critical ecological interactions (Steffan-Dewenter and Tscharntke 2002). Again, species with naturally small populations that occur in specialised floristic habitats and have restricted dietary requirements are likely to be adversely affected by fragmentation following NNG invasion due to increased demographic stochasticity, genetic decline, and impaired social function (Davies et al. 2000; Brady et al. 2011). On the other hand, at least some species appear resilient to fragmentation (Schutz and Driscoll 2008) and may even use NNGs as habitat (Richter et al. 2013). A better understanding of the characteristics of such species would greatly facilitate conservation planning in natural systems prior to $\mathrm{NNG}$ invasion.

As noted above, the impacts of NNG invasion on native vegetation are not restricted to the ground layer. New fire regimes (e.g., the grass-fire cycle) resulting in mortality of woody vegetation, for example, have been documented in A. gayanus and C. ciliaris, and are likely be a factor in areas infested with the fast-growing species $H$. hirta, E. curvula, U. mutica, and probably $P$. aquatica (Table 1). The result is significant changes to connectivity of even woody vegetation and the fauna that depend on it (e.g., Law et al. 1999; Hannah et al. 2007), particularly because smaller woody connecting elements like scattered trees and corridors may be disproportionately damaged by changes in fire intensity. This is likely to be of extreme importance in modified rural landscapes where fauna depend on remnant woody cover or isolated trees for survival (Crane et al. 2014), and where community engagement in landscape conservation is motivated by concern for woodland bird or mammal species (Amos et al. 2012; Dickman 2013). The degradation of riparian systems by NNGs (e.g., Low 1997) is also likely to be a growing driver of fragmentation and loss of functional connectivity at landscape scales for many species, since such habitats play a vital role in species movement and resource provision (e.g., Bentley and Catterall 1997; Ward et al. 1999).

\section{The management challenge}

NNGs threaten the integrity of a large number of Australian landscape connectivity and conservation initiatives (Fig. 4). Yet their control is undoubtedly an 
area of chronic policy failure (Graham 2013; Downey et al. 2010), and many appear to pose an exceptionally difficult, and probably unique, problem for agricultural and conservation land managers alike. Certainly, effective management strategies for NNGs on a sufficient scale remain elusive (Fensham et al. 2013), and determined efforts to control or eradicate codegrading species like $N$. neesiana and E. curvula (e.g., Gardener et al. 2005; Fox et al. 2009; Coutts et al. 2013) have met with minimal success. Indeed, the situation in most areas continues to deteriorate (e.g., Godfree and Stol 2015). Even Nassella trichotoma (Klepeis et al. 2009), often cited as a management success story, is still locally expanding its range and requires expensive, ongoing integrated control (Osmond et al. 2008) just to maintain the status quo. Why is this so?

It appears that the intractability of many NNGs in Australia can be traced to synergisms between the morphological, genetic and ecological attributes of invasive grasses and unique socio-ecological characteristics of the Australian land mass. In short, the most problematic NNGs tend to be difficult to recognise and to be challenging or impossible to control, even on small spatial scales. These difficulties are exacerbated by the vast spatial scale of potential habitat, social and agricultural processes that facilitate spread and establishment, and the financial constraints that arise from a low rural population density (McArdle et al. 2004; Laffan 2006; Coutts et al. 2013). More recently, the ongoing expansion of amenity landscapes in Australia (Mendham et al. 2012), in which large farming properties are subdivided and sold to landowners that value lifestyle, environmental and scenic attributes over commercial interests, has increased the complexity of organizing a coordinated, effective response to invading NNGs and other broad scale environmental challenges (Klepeis et al. 2009).

While early recognition and intervention is crucial to the control of invasive species (Westbrooks et al. 2014), grasses appear to be particularly prone to oversight or misidentification, even by experienced land managers. This is particularly true when sympatric native species have similar morphological attributes (e.g., Godfree et al. 2013), or when the production of floral parts has been affected by drought or overgrazing. For example, it is common for new populations of $H$. hirta, E. curvula, and especially Nassella spp., which are morphologically similar to
Australian native Themeda, Cymbopogon, Poa, and Austrostipa species, to go unrecognised for many years. Remote sensing techniques viable for identifying grasses, while promising (Peteinatos et al. 2014), are still in only early stages of development, and not yet widely deployed. At a broader scale, many NNGs (e.g., Themeda quadrivalvis, Cenchrus polystachios, Echinochloa polystachya) remain outside the scope of legislation or scientific research when numbers are small and control efforts would be most effective.

From an ecological perspective, the case can also be made that Australia is especially susceptible to incursion by NNGs, which severely penalizes any lack of a coordinated detection and control effort. First, the Australian land mass is dominated by grassy ecosystems (Fig. 5), key species of which have continental or sub-continental distributions (e.g., Themeda triandra). The potential range of many NNGs, especially those sourced from genetically diverse populations (Godfree et al. 2013) or bred for enhanced fitness or niche breadth (e.g., Culvenor et al. 2007; Lavergne and Molofsky 2007) is correspondingly large (Fig. 3c). Most invaders also encounter few sharp topoedaphic or climatic boundaries during the initial stages of spread, and any existing barriers are often overcome by either intentional or unintentional spread. For example, seed dispersal is augmented by Australia's network of travelling stock reserves and the freight of live animals for hundreds of kilometers or more (Hogan and Phillips 2011). Roads in remote rural areas often receive little management, and the construction and intensified use of transport corridors for the growing resource and mining sector is likely to exacerbate this problem.

The invasion process is also exacerbated by the extreme variability of the Australian climate (Sivakumar et al. 2014) and the development of agricultural practices that promote the spread and establishment of synanthropic non-native species. Australian grassy ecosystems have evolved in the absence of large herbivores since the megafaunal extinctions of $\sim 45$ kyr BP, and are especially sensitive to both the removal of ground-layer vegetation by livestock during drought and to increased soil fertility. Selective grazing favours less palatable Type I species, while pulses in soil nutrient availability following drought (Austin et al. 2004) or fertilizer application tend to benefit fast-growing, nitrophilous NNGs in general. Under these disturbance regimes, which are 
characteristic of low-intensity grazing practices over most of the continent, the spread of synanthropic NNGs often entails long periods of relative stasis punctuated by rapid expansion. The invasion on the Southern Tablelands of NSW by Nassella neesiana during and following the prolonged 2000-2009 drought is an excellent example.

From a social perspective, the development of amenity rural landscapes in Australia and elsewhere (Mendham et al. 2012), and in particular the subdivision of properties and conversion into lifestyle blocks (Klepeis et al. 2009), is also reducing the effectiveness of broad-scale NNG control programs (Coutts et al. 2013). Many people purchasing rural land have nonagricultural interests, tend to be less engaged in natural resource management and extension programs (Mendham et al. 2012), and often lack the skills necessary to identify weed species on their properties. These difficulties are exacerbated when remaining landholders, faced with heavy propagule pressure from surrounding areas, choose to simply live with NNGs. This renders the prospect of removing them from the landscape remote. Control of tradeoff-type pasture grasses like A. gayanus is even more challenging, since social conflict over their value makes coordination of management difficult or impossible, and many are at such advanced invasion state that broad scale control is now not seriously considered (Kean and Price 2003).

Finally, multi-trophic ecological interactions also limit effectiveness and desirability of broad-scale NNG control. For example, removal of $U$. mutica from aquatic systems can benefit other weeds such as Hymenachne amplexicaulis (Grice et al. 2010) and Mimosa pigra, or mobilise sediment which impacts downstream ecosystems. Similarly, some endangered species may depend on NNGs (e.g., the golden sun moth Synemon plana and Nassella neesiana) as a resource in otherwise degraded environments. Control of feral animals (such as the Asian water buffalo, Bubalus bubalis L.) may exacerbate the invasiveness of NNGs (U. mutica; Pettit et al. 2011). While some data exists on the multi-trophic effects of NNGs on fauna (e.g., U. mutica, A. gayanus and C. ciliaris), the consequences of the removal of most species, and the restoration work required to re-establish native assemblages, remains essentially guesswork. The fact that many areas now contain multiple NNGs with complementary (e.g., U. mutica, H. amplexicaulis and $E$. polystachya) or overlapping (E. curvula, $H$. hirta and N. trichotoma) niches (Table 1; Fig. 3) further increases the complexity of their control or eradication.

\section{Global significance}

We have explored the ways that NNGs transform landscapes and degrade biodiversity using Australian case studies, and why they are difficult or impossible to manage. However, invasive grasses have a strong track record of invading rangelands and other rural systems elsewhere that have much in common, both ecologically and socially, with those in Australia (e.g., D'Antonio and Vitousek 1992; DiTomaso 2009; Zenni and Ziller 2011).

Probably the best examples of NNG transformation of MRLs come from North America. Among these, the invasion of $650000 \mathrm{~km}^{2}$ of the Great Basin by Bromus tectorum (cheatgrass) is most notorious, and shares many transformational features with the case studies addressed in this paper (Knapp 1996). As in Australia, advent of the livestock grazing industry in the late nineteenth century was probably instrumental in facilitating the spread of $B$. tectorum through sagebrush ecosystems, both through seed dispersal and the destruction of native vegetation (Knapp 1996). Apart from reducing grazing capacity, B. tectorum has the capacity to radically alter nutrient flows and seasonal water availability, and to drive the transition of vegetation into alternative system states (sensu Bowman et al. 2015) in which re-establishment of native species is impossible (Knapp 1996). The direct ecological effects of $B$. tectorum invasion are exacerbated by an increase in the frequency of fire, even at regional scales (Balch et al. 2013). Interestingly, evidence is emerging that NNGs can also reduce the size and intensity of fires, leading to different trajectories of ecological change. An example is Festuca arundinaceae (McGranahan et al. 2012), which, in contrast to other NNGs, generates high-moisture fuel loads; the lower rates of spread of fire in prairies containing $F$. arundinceae ultimately result in successional change towards woodland vegetation. These and a multitude of other examples (D'Antonio and Vitousek 1992) indicate that pyrogeographical changes caused by NNGs have immense potential to 
degrade the conservation value of MRLs on a global scale.

Co-degrading NNGs appear to present land managers with broadly similar challenges in MLRs worldwide, with many species originally introduced for erosion control, revegetation or pasture improvement now degrading rangelands, remnant vegetation, or both. For example, Bothriochloa ischaemum and other old world bluestems, which are now prevalent in Texas, have low grazing value, alter fire fuel loads, exclude native vegetation, and are difficult to impossible to control (Gabbard and Fowler 2007). As in Australia, the use of intensive grazing, fire, and fertilisation are used to enhance the productivity of Eragrostis lehmanniana and other low quality species in the southern USA and elsewhere (Williams and Baruch 2000). In Brazil, private companies and government bodies promote the use of Eragrostis plana as a pasture species, despite the fact that it is often unpalatable to cattle, and it now occupies $>2$ million hectares of degraded or overgrazed steppe (citations in Zenni and Ziller 2011). These processes directly displace native species and generate agricultural intensification regimes that resemble those used in eastern Australia to manage Eragrostis curvula (e.g., Firn 2009).

Type I pasture species also appear to pose a major challenge to landscape conservation in MRLs globally. Their adoption, usually to enhance agricultural productivity, is often linked to direct and indirect loss of high conservation-value vegetation in both agricultural and non-target rangeland or grassland habitats, with similar drivers to those identified in Australia (Table 2). For example, Agropyron cristatum (Christian and Wilson 1999), Phalaris arundinaceae (Kellogg and Bridgham 2004) and Festuca arundinaceae (McGranahan et al. 2012) are serious invaders of native plant communities in North America, displacing native species and reducing biodiversity. Perhaps more importantly, however, the broad-scale clearing or modification of native vegetation to establish Type I NNG species appears to be an ongoing process worldwide. For example, the uptake of $C$. ciliaris in the Sonoran Desert region of Mexico has resulted in the clearing of extensive tracts of desert scrub, mesquite woodlands and tropical deciduous forest, with remnant areas facing ongoing invasion (Arriaga et al. 2004), even in the absence of the grass/fire cycle typical of this species (Olsson et al. 2012).
A thorough review of the relevant literature is beyond the scope of this paper, but similar case studies exist in Africa (Arundo donax and other riparian grasses; Nassella spp. and Pennisetum setaceum; Milton 2004); South America (Andropogon gayanus; Melinus minituflora; Dogra et al. 2010; Zenni and Ziller 2011), New Zealand (Lamoureaux et al. 2011), and elsewhere (Dogra et al. 2010).

\section{Conclusions and future directions}

The linkages between rural multifunctionality, landscape connectivity and invasive species are in only early stages of investigation (With 2002; Haddad et al. 2014). This is surprising, given the obvious mechanistic similarity between NNGs and other agents of landscape fragmentation documented in this paper, viz. their ability to generate a hostile landscape matrix that is impermeable to native plants and animals while simultaneously degrading core conservation areas. As we have shown, impacts on biodiversity occur via two distinct modes of socio-ecological transformation, roughly aligning with palatability and agricultural utility ("trade-off" vs. "co-degrading" species). But both are inimical to the goal of generating multifunctional rural landscapes in which agricultural production and biodiversity protection are integrated (Holmes 2006) and (ideally) mutually beneficial. The destruction of associated multi-value and conservation landscape elements also poses a major threat to broad-scale habitat connectivity initiatives, particularly those dependent on market-based protection or set-aside schemes (e.g., Windle and Rolfe 2008; Cooke and Moon 2015).

The historical track record suggests that, due to a suite of social, economic and ecological constraints, the most damaging NNGs are likely to continue to spread until new equilibria are reached (Marshall et al. 2012). In many situations change is inevitable, which makes it all the more important that we come to better understand the species and landscape-traits that underpin their impacts and which strategies, if any, may reduce them in future. With this in mind, several areas of research clearly warrant further attention.

First, in situations where land managers simply have to live with NNGs, understanding their utility in multifunctional, connected landscapes will be of 
immediate practical value. While eco-physiological distinctiveness is certainly a feature of NNGs, many have morphological and ecological similarities to native congeners or analogues (e.g., Godfree et al. 2013), and there may be substitutability among grasses that would allow for a basic level of connectivity and resource provision to be maintained, even in invaded landscapes. Perhaps some trade-off species have a smaller impact on conservation value than others, in which case prioritising their use could help retain multi-value landscape elements.

Second, we know little about the best way to design and implement connectivity and conservation initiatives when invasive, intractable NNGs are present in the landscape. This is especially true when codegrading species threaten the economic viability of mixed value agricultural properties intended for inclusion in these schemes. Perhaps a combination of early identification and triage, aggressive, targeted management of priority species and populations, and funding for cross-initiative experiments into prevention and control once they are established, may succeed. How this would work for trade-off species such as C. ciliaris is even less clear. In some cases, it may be necessary to restrict the establishment of new landscape-scale initiatives to areas where such NNGs are not yet present.

Given the growing focus on connectivity within multifunctional rural landscapes as central to the success of continental-scale biodiversity conservation, there is a need for robust solutions to these questions as a matter of priority.

Acknowledgements We would like to thank Art Langston and the Department of the Environment for generating the corridor initiative and land use overlay in Fig. 3, Josh Dorrough and Richard Groves for thoughtful discussion, and several anonymous reviewers for helpful comments. Roger Roach, Damien McMaster and Kerrie Bennison provided images used in the paper. We also thank Gary Howling and other planners and managers for helping us better understand the realities of landscape-scale conservation initiatives. Finally, we thank the Australian Government Biodiversity Fund (Grant LSP-944101899) for generous financial support.

Open Access This article is distributed under the terms of the Creative Commons Attribution 4.0 International License (http:// creativecommons.org/licenses/by/4.0/), which permits unrestricted use, distribution, and reproduction in any medium, provided you give appropriate credit to the original author(s) and the source, provide a link to the Creative Commons license, and indicate if changes were made.

\section{References}

ABARE-BRS (2010) Land use of Australia 2005-06, Version 4. http://www.agriculture.gov.au/abares/. Accessed 12 May 2015

Adie H, Richert S, Kirkman KP, Lawes MJ (2011) The heat is on: frequent high intensity fire in bracken (Pteridium aquilinum) drives mortality of the sprouting tree Protea caffra in temperate grasslands. Plant Ecol 212:2013-2022

Amos JN, Bennett AF, Mac Nally R, Newell G, Pavlova A, Radford JQ, Thomson JR, White M, Sunnucks P (2012) Predicting landscape-genetic consequences of habitat loss, fragmentation and mobility for multiple species of woodland birds. PLoS ONE 7:e30888

Argent N (2011) Trouble in paradise? Governing Australia's multifunctional rural landscapes. Aust Geogr 42:183-205

Arriaga L, Castellanos AE, Moreno E, Alarcon J (2004) Potential ecological distribution of alien invasive species and risk assessment: a case study of buffel grass in arid regions of Mexico. Conserv Biol 18:1504-1514

Asner GP, Elmore AJ, Olander LP, Martin RE, Harris AT (2004) Grazing systems, ecosystem processes, and global change. Annu Rev Environ Resour 29:261-299

Aue B, Diekötter T, Gottschalk TK, Wolters V, Hotes S (2014) How high nature value (HNV) farmland is related to bird diversity in agro-ecosystems-towards a versatile tool for biodiversity monitoring and conservation planning. Agr Ecosyst Environ 194:58-64

Austin AT, Yahdjian L, Stark JM, Belnap J, Porporato A, Norton U, Ravetta DA, Schaeffer SM (2004) Water pulses and biogeochemical cycles in arid and semiarid ecosystems. Oecologia 141:221-235

Badgery WB, Kemp DR, Michalk DL, King WM (2008) Studies of competition between Nassella trichotoma (Nees) Hack. ex Arechav. (serrated tussock) and native pastures. 1. Adult plants. Aust J Agric Res 59:226-236

Balch JK, Bradley BA, D’Antonio CM, Gómez-Dans J (2013) Introduced annual grass increases regional fire activity across the arid western USA (1980-2009). Glob Change Biol 19(1):173-183

Bardsley DK, Edwards-Jones G (2007) Invasive species policy and climate change: social perceptions of environmental change in the Mediterranean. Environ Sci Policy 10:230-242

Bart D (2006) Integrating local ecological knowledge and manipulative experiments to find the causes of environmental change. Front Ecol Environ 4:541-546

Bart D, Simon M (2013) Evaluating local knowledge to develop integrative invasive-species control strategies. Hum Ecol 41:779-788

Bentley JM, Catterall CP (1997) The use of bushland, corridors, and linear remnants by birds in southeastern Queensland, Australia. Conserv Biol 11:1173-1189

Bowman DM, Perry GL, Marston JB (2015) Feedbacks and landscape-level vegetation dynamics. Trends Ecol Evol 30:255-260

Bradby K (2013) Gondwana Link: 1000 kilometers of hope. In: Fitzsimons J, Pulsford I, Wescott G (eds) Linking Australia's landscapes. Lessons and opportunities from large- 
scale conservation networks. CSIRO Publishing, Collingwood, pp 25-36

Brady MJ, McAlpine CA, Miller CJ, Possingham HP, Baxter GS (2011) Mammal responses to matrix development intensity. Austral Ecol 36:35-45

Bredemeier B, von Haaren C, Rüter S, Reich M, Meise T (2015) Evaluating the nature conservation value of field habitats: a model approach for targeting agri-environmental measures and projecting their effects. Ecol Model 295:113-122

Broeck AV, Ceulemans T, Kathagen G, Hoffmann M, Honnay O, Mergeay J (2015) Dispersal constraints for the conservation of the grassland herb Thymus pulegioides $\mathrm{L}$. in a highly fragmented agricultural landscape. Conserv Genet 16:765-776

Brooks KJ, Setterfield SA, Douglas MM (2010) Exotic grass invasions: applying a conceptual framework to the dynamics of degradation and restoration in Australia's tropical savannas. Restor Ecol 18:188-197

Brown GW (2000) The influence of habitat disturbance on reptiles in a Box-Ironbark eucalypt forest of south-eastern Australia. Biodivers Conserv 10:161-171

Bunn SE, Davies PM, Kellway DM, Prosser IP (1998) Influence of invasive macrophytes on channel morphology and hydrology in an open tropical lowland stream, and potential control by riparian shading. Freshw Biol 39:171-178

Buskirk Van, Willi Y (2004) Enhancement of farmland biodiversity within set-aside land. Conserv Biol 18:987-994

Campbell MH, Vere DT (1995) Nassella trichotoma (Nees) Arech. In: Groves RH, Shepherd RCH, Richardson RG (eds) The biology of Australian Weeds, vol 1. RG and FJ Richardson, Melbourne, pp 189-202

Christian JM, Wilson SD (1999) Long-term ecosystem impacts of an introduced grass in the northern Great Plains. Ecology 80:2397-2407

Cooke B, Moon K (2015) Aligning 'public good'environmental stewardship with the landscape-scale: adapting MBIs for private land conservation policy. Ecol Econ 114:152-158

Coutts SR, Yokomizo H, Buckley YM (2013) The behavior of multiple independent managers and ecological traits interact to determine prevalence of weeds. Ecol Appl 23:523-536

Crane MJ, Lindenmayer DB, Cunningham RB (2014) The value of countryside elements in the conservation of a threatened arboreal marsupial Petaurus norfolcensis in agricultural landscapes of south-eastern Australia - the disproportional value of scattered trees. PLoS ONE 9:e107178

Crooks KR, Sanjayan M (2006) Connectivity conservation. Cambridge University Press, Cambridge

Culvenor RA, Boschma SP, Reed KFM (2007) Persistence of winter-active phalaris breeding populations, cultivars and other temperate grasses in diverse environments of southeastern Australia. Aust J Exp Agric 47:136-148

Daehler CC (2003) Performance comparisons of co-occurring native and alien invasive plants: implications for conservation and restoration. Annu Rev Ecol Evol Syst 34:183-211

Davies KF, Margules CR, Lawrence JF (2000) Which traits of species predict population declines in experimental forest fragments? Ecology 81:1450-1461

de Castro EBV, Fernandez FAS (2004) Determinants of differential extinction vulnerabilities of small mammals in Atlantic forest fragments in Brazil. Biol Cons 119:73-80
Diacon-Bolli JC, Edwards PJ, Bugmann H, Scheidegger C, Wagner HH (2013) Quantification of plant dispersal ability within and beyond a calcareous grassland. J Veg Sci 24:1010-1019

Dickman CR (2013) Human community ecology: making connections for conservation. Pac Conserv Biol 19:312-319

DiTomaso JM (2009) Invasive weeds in rangelands: species, impacts, and management. Weed Sci 48:255-265

Doerr VAJ, Doerr ED, Davies MJ (2010) Systematic review \#44: does structural connectivity facilitate dispersal of native species in Australia's fragmented terrestrial landscapes? Collaboration for environmental evidence, Bangor. http://environmentalevidence.org/SR44.html

Doerr VAJ, Barrett T, Doerr ED (2011) Connectivity, dispersal behaviour and conservation under climate change: a response to Hodgson et al. J Appl Ecol 48:143-147

Dogra KS, Sood SK, Dobhal PK, Sharma S (2010) Alien plant invasion and their impact on indigenous species diversity at global scale: a review. J Ecol Nat Environ 2:175-186

Dorrough J, McIntyre S, Scroggie MP (2011) Individual plant species responses to phosphorous and livestock grazing. Aust J Bot 59:670-681

Downey PO, Williams MC, Whiffen LK, Auld BA, Hamilton MA, Burley AL, Turner PJ (2010) Managing alien plants for biodiversity outcomes-the need for triage. Invasive Plant Sci Manag 3:1-11

Doxa A, Paracchini ML, Pointereau P, Devictor V, Jiguet F (2012) Preventing biotic homogenization of farmland bird communities: the role of high nature value farmland. Agr Ecosyst Environ 148:83-88

Driscoll DA, Catford JA, Barney JN, Hulme PE, Martin TG, Pauchard A, Pyšek P, Richardson DM, Riley S, Visser V (2014) New pasture plants intensify invasive species risk. Proc Natl Acad Sci USA 111:16622-16627

D’Antonio CM, Vitousek PM (1992) Biological invasions by exotic grasses, the grass/fire cycle, and global change. Annu Rev Ecol Syst 23:63-87

D’Antonio CM, Hughes RF, Tunison JT (2011) Long-term impacts of invasive grasses and subsequent fire in seasonally dry Hawaiian woodlands. Ecol Appl 21:1617-1628

Eamer JBR, Darke IA, Walker IJ (2013) Geomorphic and sediment volume responses of a coastal dune complex following invasive vegetation removal. Earth Process Landf 38:1148-1159

Ehrenfeld JG (2003) Effects of exotic plant invasions on soil nutrient cycling processes. Ecosystem 6:503-523

Ehrenfeld JG (2010) Ecosystem consequences of biological invasions. Annu Rev Ecol Evol Syst 41:59-80

Fensham RJ, Donald S, Dwyer JM (2013) Propagule pressure, not fire or cattle grazing, promotes invasion of buffel grass Cenchrus ciliaris. J Appl Ecol 50:138-146

Ferdinands K, Beggs K, Whitehead P (2005) Biodiversity and invasive grass species: multiple-use or monoculture? Wildl Res 32:447-457

Firn J (2009) African lovegrass in Australia: a valuable pasture species or embarrassing invader? Trop Grassl 43:86-97

Firn J, House APN, Buckley YM (2010) Alternative states models provide an effective framework for invasive species control and restoration of native communities. J Appl Ecol 47:96-105 
Firn J, Price JN, Whalley RDB (2013) Using strategically applied grazing to manage invasive alien plants in novel grasslands. Ecol Process 2:1-11

Fox JC, Buckley YM, Panetta FD, Bourgoin J, Pullar D (2009) Surveillance protocols for management of invasive plants: modelling Chilean needle grass (Nassella neesiana) in Australia. Divers Distrib 15:577-589

Franklin KA, Lyons K, Nagler PL, Lampkin D, Glenn EP, Molinea-Freaner F, Markow T, Huete AR (2006) Buffelgrass (Pennisetum ciliare) land conversion and productivity in the plains of Sonora, Mexico. Biol Cons 127:62-71

Friedel MH, Grice AC, Marshall NA, van Klinken RD (2011) Reducing contention amongst organisations dealing with commercially valuable but invasive plants: the case of buffel grass. Environ Sci Policy 14:1205-1218

Gabbard BL, Fowler NL (2007) Wide ecological amplitude of a diversity-reducing invasive grass. Biol Invasions 9:149-160

Gardener MR, Sindel BM, Whalley RBD, Earl JM (2005) Can Nassella neesiana, Chilean needle grass, be incorporated into a grazing management system in Australia? Plant Prot Q 2:36-40

Gardener MR, Whalley RBD, Sindel BM (2003) Ecology of Nassella neesiana, Chilean needle grass, in pastures on the Northern Tablelands of New South Wales. I. Seed production and dispersal. Aust J Agric Res 54:613-619

Godfree RC, Robertson BC, Gapare WJ, Ivković M, Marshall DJ, Lepschi BJ, Zwart AB (2013) Nonindigenous plant advantage in native and exotic Australian grasses under experimental drought, warming, and atmospheric $\mathrm{Co}_{2}$ enrichment. Biology 2:481-513

Godfree RC, Stol JM (2015) Initial identification and prioritisation of weeds of conservation management areas in the Kosciuszko to Coast (K2C) corridor of New South Wales, Australia. Plant Prot Q 30:86-92

Graham S (2013) Three cooperative pathways to solving a collective weed management problem. Australas J Environ Manag 20:116-129

Grassini P, Eskridge KM, Cassman KG (2013) Distinguishing between yield advances and yield plateaus in historical crop production trends. Nat Commun 4:2918

Grech CJ, McLaren DA, Lowien J, McWhirter L, Butler KL, Sindel BM (2014) Assessment of management options for Chilean needlegrass in sheep-grazing systems. Grass Forage Sci 36:119-128

Grice AC (2006) The impacts of invasive plant species on the biodiversity of Australian rangelands. Rangel J 28:27-35

Grice T, Nicholas M, Williams P, Collins E (2010) 4.3 Using fire to manage para grass in wetlands: a Queensland case study. Kakadu National Park Landscape Symposia Series 2007-2009, Symposium 3: fire management. Aurora Kakadu, 23-24 April 2008, p 80-90

Grice AC, Friedel MH, Marshall NA, Van Klinken RD (2012) Tackling contentious invasive plant species: a case study of buffel grass in Australia. Environ Manag 49:285-294

Groves R, Whalley R (2002) Grass and grassland ecology in Australia. Flora Aust 43:157-182

Haddad NM, Brudvig LA, Damschen EI, Evans DM, Johnson BL, Levey DJ, Orrock JL, Resasco J, Sullivan LL, Tewksbury JJ, Wagner SA, Weldon AJ (2014) Potential negative ecological effects of corridors. Conserv Biol 28:1178-1187

Hannah D, Woinarski JCZ, Catterall CP, McCosker JC, Thurgate NY, Fensham RJ (2007) Impacts of clearing, fragmentation and disturbance on the bird fauna of Eucalypt savanna woodlands in central Queensland, Australia. Austral Ecol 32:261-276

Hattersley PW (1983) The distribution of $\mathrm{C}_{3}$ and $\mathrm{C}_{4}$ grasses in Australia in relation to climate. Oecologia 57:113-128

Hayes N, Morrison-Saunders A (2007) Effectiveness of environmental offsets in environmental impact assessment: practitioner perspectives from Western Australia. Impact Assess Proj Apprais 25:209-218

Henle K, Davies KF, Kleyer M, Margules C, Settele J (2004) Predictors of species sensitivity to fragmentation. Biodivers Conserv 13:207-251

Hill JO, Simpson RJ, Wood JT, Moore AD, Chapman DF (2005) The phosphorous and nitrogen requirements of temperate pasture species and their influence on grassland botanical composition. Aust J Agric Res 56:1027-1039

Hilty JA, Lidicker WZ, Merenlender AM (2006) Corridor ecology: the science and practice of linking landscapes for biodiversity conservation. Island Press, Washington, D.C.

Hobbs RJ, Yates CJ (2003) Turner review no. 7: impacts of ecosystem fragmentation on plant populations: generalising the idiosyncratic. Aust J Bot 2003:471-488

Hoffmeister TS, Vet LEM, Biere A, Holsinger K, Filser J (2005) Ecological and evolutionary consequences of biological invasion and habitat fragmentation. Ecosystems 8:657-667

Hogan JP, Phillips CJC (2011) Transmission of weed seed by livestock: a review. Anim Prod Sci 51:391-398

Holmes J (2006) Impulses towards a multifunctioning transition in rural Australia: gaps in the research agenda. J Rural Stud 22:142-160

Holmes TH, Rice KJ (1996) Patterns of growth and soil-water utilization in some exotic annuals and native perennial bunchgrasses of California. Ann Bot 78:233-243

Johnston WH, Cornish PS, Shoemark VF (2005) Eragrostis curvula (Schrad.) Nees. complex pastures in southern New South Wales, Australia: a comparison with Medicago sativa L. and Phalaris aquatica L. pastures under rotational grazing. Anim Prod Sci 45:401-420

Johnston WH, Garden DL, Rančič A, KoenTB Dassanayake KB, Langford CM, Ellis NJS, Rab MA, Tuteja NK, Mitchell M, Wadsworth J, Dight D, Holbrook K, LeLievre R, McGeoch SM (2003) The impact of pasture development and grazing on water-yielding catchments in the Murray-Darling Basin in south-eastern Australia. Aust J Exp Agric 43:817-841

Jordan NR, Larson DL, Huerd SC (2008) Soil modification by invasive plants: effects of native and invasive species of mixed-grass prairies. Biol Invasions 10:177-190

Kean L, Price O (2003) The extent of mission grasses and Gamba Grass in the Darwin region of Australia's Northern Territory. Pac Conserv Biol 8:281-290

Kellogg CH, Bridgham SD (2004) Disturbance, herbivory, and propagule dispersal control dominance of an invasive grass. Biol Invasions 6:319-329

Klepeis P, Gill N, Chisholm L (2009) Emerging amenity landscapes: invasive weeds and land subdivision in rural Australia. Land Use Policy 26:380-392 
Knapp PA (1996) Cheatgrass (Bromus tectorum L) dominance in the Great Basin Desert: history, persistence, and influences to human activities. Glob Environ Change 6:37-52

Kröger M (2014) The political economy of global tree plantation expansion: a review. J Peasant Stud 41:235-261

Laffan SW (2006) Assessing regional scale weed distributions, with an Australian example using Nassella trichotoma. Weed Res 46:194-206

Lamoureaux SL, Bourdôt GW, Saville DJ (2011) Population growth of Nassella trichotoma in grasslands in New Zealand slower today than in the past. Acta Oecologica 37:484-494

Larson BMH (2008) Entangled biological, cultural, and linguistic origins of the war on invasive species. In: Frank R, Dirven R, Ziemke T, Bernárdez E (eds) Body, language and mind., Volume 2: Sociocultural situatednessMouton de Gruyter, New York, pp 169-195

Lavergne S, Molofsky J (2007) Increased genetic variation and evolutionary potential drive the success of an invasive grass. Proc Natl Acad Sci 104:3883-3888

Law BS, Anderson J, Chidel M (1999) Bat communities in a fragmented forest landscape on the south-west slopes of New South Wales, Australia. Biol Cons 88:333-345

Le QB, Nkonya E, Mirzabaev A (2014) Biomass productivitybased mapping of global land degradation hotspots. ZEF Discussion Papers on Development Policy No. 193, Center for Development Research, Bonn, $57 \mathrm{p}$

Lodge GM, McCormick LH, Harden S (2005) Grazing studies of a Hyparrhenia hirta (Coolatai grass) pasture in northern New South Wales. Aust J Exp Agric 45:1603-1611

Lodge GM, McMillan MG, McCormick LH, Cook AS (1994) Effects of glyphosate, flupropanate and 2,2-DPA on $\mathrm{Hy}$ parrhenia hirta (L.) Stapf (Coolatai grass). Aust J Exp Agric 34:479-485

Low T (1997) Tropical pasture plants as weeds. Tropical Grasslands 31:337-343

Ludwig JA, Tongway DJ (1996) Rehabilitation of semiarid landscapes in Australia. II. Restoring vegetation patches. Restor Ecol 4:398-406

Mac Nally R, Brown GW (2001) Reptiles and habitat fragmentation in the box-ironbark forests of central Victoria, Australia: predictions, compositional change and faunal nestedness. Oecologia 128:116-125

MacDougall AS, Bennett JR, Firn J, Seabloom EW, Borer ET, Lind EM, Orrock JL, Harpole WS, Hautier Y, Adler PB, Cleland E, Davies KF, Melbourne BA, Prober SM, Bakker JD, Fay PA, Jin VL, Kendig A, La Pierre KJ, Moore JL, Morgan JW, Stevens CJ (2014) Anthropogenic-based regional-scale factors most consistently explain plot-level exotic diversity in grasslands. Glob Ecol Biogeogr 23:802-810

MacDougall AS, McCann KS, Gellner G, Turkington R (2013) Diversity loss with persistent human disturbance increases vulnerability to ecosystem collapse. Nature 494:86-89

MacDougall AS, Turkington R (2005) Are invasive species the drivers or passengers of change in degraded ecosystems? Ecology 86:42-55

Mackey BG, Watson J, Worboys GL (2010) Connectivity conservation and the Great Eastern Ranges corridor. An independent report to the Interstate Agency Working Group (Alps to Atherton Connectivity Conservation
Working Group) convened under the Environment Heritage and Protection Council/Natural Resource Management Ministerial Council, ANU Enterprises Pty Ltd

Mansergh I, Cheal D, Fitzsimons JA (2008) Future landscapes in South-eastern Australia: the role of protected areas and biolinks in adaptation to climate change. Biodiversity 9:59-70

Margules CR, Pressey RL (2000) Systematic conservation planning. Nature 405:243-253

Marshall K, Hamlin J, Armstrong M, Mendoza J, Lee C, Pieri D, Rivera R, Lastra-Diaz L, Stonefish A, Bailey J (2011) Science for a social revolution: ecologists entering the realm of action. ESA Bull 92:241-243

Marshall VM, Lewis MM, Ostendorf B (2012) Buffel grass (Cenchrus ciliaris) as an invader and threat to biodiversity in arid environments: a review. J Arid Environ 78:1-12

Marvier M, Karieva P, Neubert MG (2004) Habitat destruction, fragmentation, and disturbance promote invasion by habitat generalists in a multispecies metapopulation. Risk Anal 24:869-878

Mattson DJ, Clark SG, Byrd KL, Brown SR, Robinson B (2011) Leaders' perspectives in the Yellowstone to Yukon conservation initiative. Policy Sci 44:103-133

McArdle SL, Nadolny C, Sindel BM (2004) Invasion of native vegetation by Coolatai grass Hyparrhenia hirta: impacts on native vegetation and management implications. Pac Conserv Biol 10:49-56

McCarthy J (2005) Rural geography: multifunctional rural geographies-reactionary or radical? Prog Hum Geogr 29:773

McGranahan DA, Engle DM, Fuhlendorf SD, Miller JR, Debinski DM (2012) An invasive cool-season grass complicates prescribed fire management in a native warmseason grassland. Nat Areas J 32:208-214

McIntyre S, Hobbs R (1999) A framework for conceptualizing human effects on landscapes and its relevance to management and research models. Conserv Biol 13:1282-1292

McLaren DA, Morfe TA, Weiss J (2002) Distribution, economic impact and attitudes towards Chilean needlegrass (Nassella neesiana (Trin. \& Rupr.) Barkworth) in Australia. Plant Protection Society of Western Australia, Perth, pp 749-752

Mendham E, Curtis A, Millar J (2012) The natural resource management implications of rural property turnover. Ecol Soc 17:5

Miller G, Friedel M, Adam P, Chewings V (2010) Ecological impacts of buffel grass (Cenchrus ciliaris L.) invasion in central Australia-does field evidence support a fire-invasion feedback? Rangel J 32:353-365

Moilanen A, Franco AMA, Early RI, Fox R, Wintle B, Thomas CD (2005) Prioritizing multiple-use landscapes for conservation: methods for large multi-species planning problems. Proc R Soc B 272:1885-1891

Moore RM (1970) South-eastern temperate woodlands and grasslands. In: Moore RM (ed) Australian Grasslands, 1st edn. ANU Press, Canberra, pp 169-190

Morefield PE, LeDuc SD, Clark CM, Iovanna R (2016) Grasslands, wetlands, and agriculture: the fate of land expiring from the conservation reserve program in the Midwestern United States. Environ Res Lett 11:094005

Mott JJ, Groves RH (1994) Natural and derived grasslands. Australian vegetation. Cambridge University Press, Cambridge, pp 369-392 
Murphy HT, Lovett-Doust J (2004) Context and connectivity in plant metapopulations and landscape mosaics: does the matrix matter? Oikos 105:3-14

O'Reagain P, Scanlan J, Hunt L, Cowley R, Walsh D (2014) Sustainable grazing management for temporal and spatial variability in north Australian rangelands-a synthesis of the latest evidence and recommendations. Rangel J 36:223-232

Olsson AD, Betancourt J, McClaran MP, Marsh SE (2012) Sonoran desert ecosystem transformation by a $\mathrm{C} 4$ grass without the grass/fire cycle. Divers Distrib 18:10-21

Osmond R, Veebeek M, McLaren DA, Michelmore M, Wicks B, Grech CJ, Fullerton P (2008) Serrated tussock-national best practice manual. Victorian Department of Primary Industries

Perna CN, Cappo M, Pusey BJ, Burrows DW, Pearson RG (2012) Removal of aquatic weeds greatly enhances fish community richness and diversity: an example from the Burdekin River floodplain, tropical Australia. River Res Appl 28:1093-1104

Peteinatos GG, Weis M, Andújar D, Rueda Ayala V, Gerhards R (2014) Potential use of ground-based sensor technologies for weed detection. Pest Manag Sci 70:190-199

Pettit NE, Bayliss P, Davies PM, Hamilton SK, Warfe DM, Bunn SE, Douglas MM (2011) Seasonal contrasts in carbon resources and ecological processes on a tropical floodplain. Freshw Biol 56:1047-1064

Polyakov M, Pannell DJ, Pandit R, Tapsuwan S, Park G (2014) Capitalized amenity value of native vegetation in a multifunctional rural landscape. Am J Agric Econ 97:299-314

Pulsford I, Howling G, Dunn R, Crane R (2013) The great eastern ranges initiative: a continental-scale lifeline connecting people and nature. In: Fitzsimons J, Pulsford I, Wescott G (eds) Linking Australia's Landscapes. Lessons and opportunities from large-scale conservation networks. CSIRO Publishing, Collingwood, pp 123-234

Reed KFM (2014) Perennial pasture grasses-an historical review of their introduction, use and development for southern Australia. Crop Pasture Sci 65:691-712

Richter A, Osborne W, Hnatiuk S, Rowell A (2013) Moths in fragments: insights into the biology and ecology of the Australian endangered golden sun moth Synemon plana (Lepidoptera: Castniidae) in natural temperate and exotic grassland remnants. J Insect Conserv 17:1093-1104

Rossiter NA, Setterfeld SA, Douglas MM, Hutley LB (2003) Testing the grass-fire cycle: alien grass invasion in the tropical savannas of northern Australia. Divers Distrib 9:169-176

Rossiter-Rachor NA, Setterfeld SA, Douglas MM, Hutley LB, Cook GD, Schmidt S (2009) Invasive Andropogon gayanus (gamba grass) is an ecosystem transformer of nitrogen relations in Australian savanna. Ecol Appl 19:1546-1560

Schlesinger C, White S, Muldoon S (2013) Spatial pattern and severity of fire in areas with and without buffel grass (Cenchrus ciliaris) and effects on native vegetation in central Australia. Austral Ecol 38:831-840

Schutz AJ, Driscoll DA (2008) Common reptiles unaffected by connectivity or condition in a fragmented farming landscape. Austral Ecol 33:641-652

Setterfield SA, Rossiter-Rachor NA, Hutley LB, Douglas MM, Williams RJ (2010) Biodiversity research: turning up the heat: the impacts of Andropogon gayanus (gamba grass) invasion on fire behaviour in northern Australian savannas. Divers Distrib 16:854-861

Simberloff D, Von Holle B (1999) Positive interactions of nonindigenous species: invasional meltdown? Biol Invasions 1:21-32

Sivakumar B, Woldemeskel FM, Puente CE (2014) Nonlinear analysis of rainfall variability in Australia. Stoch Environ Res Risk Assess 28:17-27

Smith FP, Prober SM, House APN, McIntyre S (2013) Maximizing retention of native biodiversity in Australia agricultural landscapes - The 10:20:40:30 guidelines. Agric Ecosyst Environ 166:35-45

Snell K, Grech C, Jamie D (2007) National best practise management manual-Chilean needle grass. Victorian Government, Department of Primary Industries, Melbourne

Soons MB, Messelink JH, Jongejans E, Heil GW (2005) Habitat fragmentation reduces grassland connectivity for both short- and long-distance wind dispersal forbs. J Ecol 93:1214-1225

Soulé ME, Mackey BG, Recher HF, Williams JE, Woinarski JCZ, Driscoll D, Dennison WC, Jones ME (2004) The role of connectivity in Australian conservation. Pac Conserv Biol 10:266-279

Steffan-Dewenter I, Tscharntke T (2002) Insect communities and biotic interactions on fragmented calcareous grasslands-a mini review. Biol Conserv 104:275-284

Stone LM, Byrne M, Virtue JG (2008) An environmental weed risk assessment model for Australian forage improvement programs. Aust J Exp Agric 48:568-574

Strayer DL (2012) Eight questions about invasions and ecosystem functioning. Ecol Lett 15:1199-1210

Stutter MI, Chardon WJ, Kronvang B (2012) Riparian buffer strips as a multifunctional management tool in agricultural landscapes: introduction. J Environ Qual 41:297-303

Sullivan CA, Skeffington MS, Gormally MJ, Finn JA (2010) The ecological status of grasslands on lowland farmlands in western Ireland and implications for grassland classification and nature value assessment. Biol Cons 143:1529-1539

Tilman D (1999) Global environmental impacts of agricultural expansion: the need for sustainable and efficient practices. Proc Natl Acad Sci 96:5995-6000

Tothill JC, McDonald CK, McHarg GW, Hargreaves JNG (2008) Development options in Heteropogon contortus grasslands in south-east Queensland: tree killing, legume oversowing and pasture replacement. Trop Grassl 42:129-151

Trémont RM, McIntyre S (1994) Natural grassy vegetation and native forbs in temperate Australia: structure, dynamics and life histories. Aust J Bot 42:641-658

Van Der Windt HJ, Swart JAA (2008) Ecological corridors, connecting science and politics: the case of the Green River in the Netherlands. J Appl Ecol 45:124-132

Ward JV, Tockner K, Schiemer F (1999) Biodiversity of floodplain river ecosystems: ecotones and connectivity. Regul Rivers 15:125-139

Westbrooks RG, Manning ST, Waugh JD, Ziska LH, Dukes JS (2014) Early detection and rapid response: a cost-effective strategy for minimizing the establishment and spread of new and emerging invasive plants by global trade, travel 
and climate change. Invasive Species Glob, Climate Change, pp 305-325

Whitten SM, Freudenberger D, Wyborn C, Doerr V, Doerr E (2011) A compendium of existing and planned Australian wildlife corridor projects and initiatives, and case study analysis of operational experience. A report for the Australian Government Department of Sustainability, Environment, Water, Population and Communities, CSIRO Ecosystem Sciences, June 2011

Wildin JH (1985) Pastures in artificial ponds for dry season grazing in tropical Australia. Proceedings of the XV international grassland congress, Kyoto, 24-31 Aug 1985. pp 1303-1304

Williams DG, Baruch Z (2000) African grass invasion in the Americas: ecosystem consequences and the role of ecophysiology. Biol Invasions 2:123-140

Williams NS, Morgan JW, McCarthy MA, McDonnell MJ (2006) Local extinction of grassland plants: the landscape matrix is more important than patch attributes. Ecology 87:3000-3006

Windle J, Rolfe J (2008) Exploring the efficiencies of using competitive tenders over fixed price grants to protect biodiversity in Australian rangelands. Land Use Policy 25:388-398
With KA (2002) The landscape ecology of weed spread. Conserv Biol 16:1192-1203

Wolkovich EM, Bolger DT, Holway DA (2009) Complex responses to invasive grass litter by ground arthropods in a Mediterranean scrub ecosystem. Oecologia 161:697-708

Worboys GL (2010) The connectivity conservation imperative. In: Worboys GL, Francis WL, Lockwood M (eds) Connectivity conservation management-a global guide. Earthscan, London

Worboys GL, Pulsford I (2011) Connectivity conservation in Australian landscapes. Report prepared for the Australian government department of sustainability, environment, water, population and communities on behalf of the State of the Environment 2011 committee. DSEWPaC, Canberra, 2011

Zenni RD, Ziller SR (2011) An overview of invasive plants in Brazil. Braz J Bot 34:431-446

Zhang H, Turner NC, Poole ML, Simpson N (2006) Crop production in the high rainfall zones of southern Australiapotential, constraints and opportunities. Anim Prod Sci 46:1035-1049 